\title{
PROMETHEUS: A Copper-Based Polymetallic Catalyst for Automotive Applications. Part II: Catalytic Efficiency an Endurance as Compared with Original Catalysts
}

\author{
Iakovos Yakoumis*(D), Ekaterini Polyzou and Anastasia Maria Moschovi
}

MONOLITHOS Catalysts \& Recycling Ltd., 11476 Athens, Greece; kpolyzou@monolithos.gr (E.P.); moschovi@monolithos.gr (A.M.M.)

* Correspondence: yakoumis@monolithos-catalysts.gr; Tel.: +30-210-645-0106

check for

updates

Citation: Yakoumis, I.; Polyzou, E.; Moschovi, A.M. PROMETHEUS: A Copper-Based Polymetallic Catalyst for Automotive Applications. Part II: Catalytic Efficiency an Endurance as Compared with Original Catalysts. Materials 2021, 14, 2226. https://doi. org/10.3390/ma14092226

Academic Editor: Radu Robert Piticescu

Received: 10 March 2021

Accepted: 20 April 2021

Published: 26 April 2021

Publisher's Note: MDPI stays neutral with regard to jurisdictional claims in published maps and institutional affiliations.

Copyright: (C) 2021 by the authors. Licensee MDPI, Basel, Switzerland. This article is an open access article distributed under the terms and conditions of the Creative Commons Attribution (CC BY) license (https:/ / creativecommons.org/licenses/by/ $4.0 /)$.

\begin{abstract}
PROMETHEUS catalyst, a copper-based polymetallic nano-catalyst has been proven to be suitable for automotive emission control applications. This novel catalyst consists of copper, palladium and rhodium nanoparticles as active phases, impregnated on an inorganic oxide substrate, $\mathrm{CeO}_{2} / \mathrm{ZrO}_{2}(75 \%, 25 \%)$. The aim of PROMETHEUS catalyst's development is the substitution of a significant amount (85\%) of Platinum Group Metals (PGMs) with copper nanoparticles while, at the same time, presenting high catalytic efficiency with respect to the commercial catalysts. In this work, an extensive investigation of the catalytic activity of full scale PROMETHEUS fresh and aged catalyst deposited on ceramic cordierites is presented and discussed. The catalytic activity was tested on an Synthetic Gas Bench (SGB) towards the oxidation of $\mathrm{CO}$ and $\mathrm{CH}_{4}$ and the reduction of NO. The loading of the washcoat was $2 \mathrm{wt} \%$ (metal content) on $\mathrm{Cu}, \mathrm{Pd}, \mathrm{Rh}$ with the corresponding metal ratio at 21:7:1. The concentration of the full-scale monolithic catalysts to be $0.032 \%$ total PGM loading for meeting Euro III standard and $0.089 \%$ for meeting Euro IV to Euro VIb standards. The catalytic activity of all catalysts was tested both in rich-burn $(\lambda=0.99)$ and lean-burn conditions $(\lambda=1.03)$.
\end{abstract}

Keywords: PROMETHEUS catalyst; copper; catalytic converter; platinum group metals; automotive

\section{Introduction}

The increase of vehicle fleet during the last few decades has been linked with serious environmental impacts such as climate change and the greenhouse effect. Additionally, the increased population of the large urban centers is linked to the increased use of vehicles, one of main causes of air pollution in large cities. One of the precautionary measures to improve and reduce pollution from the use of fossil fuels is the strictest and lowest emission limits for cars. For many years, catalytic converters have been an effective way to reduce harmful gases emitted by internal combustion engines. Stricter emission limits for vehicles set in recent years have led to the development of new catalysts, which are characterized by higher concentrations of PGMs, compared to former generation of catalysts. The demand for higher quantities of PGMs to produce state-of-the-art catalysts also reveals an important economic aspect of the issue. The price of PGMs has increased significantly in the past 5 years $(+165.68 \%$ for platinum, $+467.26 \%$ for palladium and $+1490.30 \%$ for rhodium $)$ [1], while their supply is dependent on few producers and at the same time their substitution remains difficult. It is, therefore, easy to understand that the development of new catalytic systems that combine high efficiency with lower use of PGMs is a challenge for the research community, both for environmental and economic reasons [2].

An ideal new catalyst would be one that could combine high reactivity with one metal or a combination of metals characterized by high physical abundance and low cost. Copper, which has been increasingly used in catalytic applications over the last two decades, could be regarded as a proper candidate. The high natural abundance of copper, compared with precious metals, the interesting applications in organic synthesis (e.g., 
Gilman reagents or as co-catalyst in Sonogashira reaction) and its catalytic properties, is an attractive background [3-5]. The increased research interest and the development of new catalytic systems-based on copper is reflected in the multiple publications and the variety of catalytic applications that include homogeneous and heterogeneous catalytic systems. New homogeneous catalytic systems-based on copper catalysts presenting remarkable results have applied successfully in organic synthesis reactions. In many cases, the aim of the researchers is to replace palladium or precious metals catalysts with copper catalysts, e.g., copper catalyzed Sonoghasira coupling reaction $[4,5]$. These efforts are extended to even more sophisticated reactions such $\mathrm{C}-\mathrm{H}$ activation reactions $[6,7]$. On the other hand, heterogeneous copper-based catalytic systems demonstrate extremely interesting catalytic properties, especially in oxidation reactions. Various catalytic systems of supported copper catalysts have been applied successfully in the oxidation of CO [8-19].

Pacella et al. presented nanocomposites in which $\mathrm{CuO}$ nanoparticles were highly dispersed on active $\mathrm{LaCoO}_{3}$ by an Ammonium-Driving-Deposition participation (ADP) procedure. The aim of the above research was the development of Platinum Group Metal (PGM) free catalysts for applications as Three-Way Catalytic Converters (TWC). Catalysts' performance was tested in conditions approaching the effective automotive exhaust. A high efficiency with $85-90 \%$ CO conversion was observed at $250{ }^{\circ} \mathrm{C}$ and $100 \% \mathrm{NO}$ conversion at $400{ }^{\circ} \mathrm{C}$, under fuel-rich conditions [20]. $\mathrm{Ce}-\mathrm{Cu}$ and $\mathrm{Ce}-\mathrm{Zr}-\mathrm{Cu}$ oxide systems with a flower-like morphology (FCCu and FCZCu, respectively) have been synthesized by slow co-precipitation method and calcined in air flow at $650{ }^{\circ} \mathrm{C}$. The samples produced were characterized with various methods and were used as catalysts for the preferential oxidation of $\mathrm{CO}$ in excess of $\mathrm{H}_{2}$. The catalytic experiments took place in $80-190{ }^{\circ} \mathrm{C}$ temperature range. Both catalysts showed similar catalytic behavior below $140^{\circ} \mathrm{C}$, maintaining high $\mathrm{CO}$ conversion levels above $160^{\circ} \mathrm{C}$ with FCZCu catalyst activity remaining constant at about $100 \%$ up to $190{ }^{\circ} \mathrm{C}$. The selectivity to $\mathrm{CO}_{2}$ over the $\mathrm{FCCu}$ catalyst was sharply decreased above $90{ }^{\circ} \mathrm{C}$ with the exception of FCZCu that remained selective up to $115^{\circ} \mathrm{C}(98 \%)$ [21].

$\mathrm{CuO} / \mathrm{CeO}_{2}$ catalysts were produced by impregnation using different $\mathrm{Cu}$ precursors, such as acetate, chloride, nitrate or sulphate. The samples were calcined at 500 and $800{ }^{\circ} \mathrm{C}$ and their physicochemical properties were determined. The results showed that $\mathrm{CuO}$ was the dominant $\mathrm{Cu}$ phase in all cases. $\mathrm{CuO} / \mathrm{CeO}_{2}$ prepared from copper acetate and calcined at $500{ }^{\circ} \mathrm{C}$ presented the best catalytic results due to the better dispersion of $\mathrm{CuO}$ as well as enhanced $\mathrm{CuO}-\mathrm{CeO}_{2}$ synergistic effects [22]. In addition, Avgouropoulos et al. presented the synthesis of copper-ceria catalysts by a hydrothermal method employing citric acid as a chelating agent, sodium hydroxide as the precipitating agent and different copper precursors (nitrate salt and metallic ring). The catalysts were tested for $\mathrm{CO}$ oxidation reaction in the temperature range of $25-400{ }^{\circ} \mathrm{C}$, at atmospheric pressure, using a fixed-bed reactor system. Finally, Avgouropoulos group proved that (i) the catalyst prepared with metallic ring as the copper precursor, named $\mathrm{CuCe}-\mathrm{CR}$, achieved $\mathrm{CO}$ conversion higher than $99.5 \%$ at $215^{\circ} \mathrm{C}$ compared to the catalyst prepared with nitrate salt as the copper precursor $(\mathrm{CuCe}-\mathrm{CN})$ which showed similar catalytic efficiency at $\sim 245^{\circ} \mathrm{C}$ and (ii) high catalytic activity depends on the nature of atomically dispersed $\mathrm{Cu}^{2+}$ clusters and not on the specific surface area and concentration of oxygen vacancies [23].

As a result, due to the reported ability of copper to catalyze oxidation reactions, it has been investigated as an active metal in the synthesis of Three-Way Catalytic converters (TWC). Although many efforts have been made in the field of Automotive industry, PROMETHEUS is the first catalyst produced initially in lab-scale and subsequently in full scale (Figure 1), designed-based on the synergistic effects between copper, noble metals and the high ionic conductivity or oxygen storage capacity of the ceramic carrier, in order to achieve high catalytic activity [24]. It is a disruptive technology since EURO regulations have become more and more severe regarding the use of PGMs ( $\mathrm{Pt}, \mathrm{Pd}, \mathrm{Rh})$. 


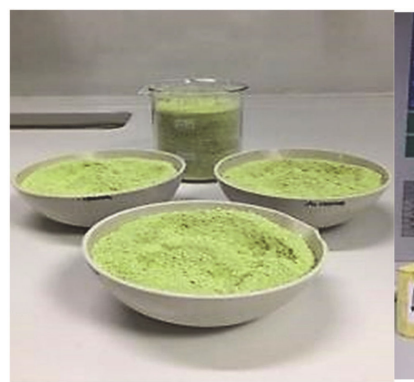

(a)

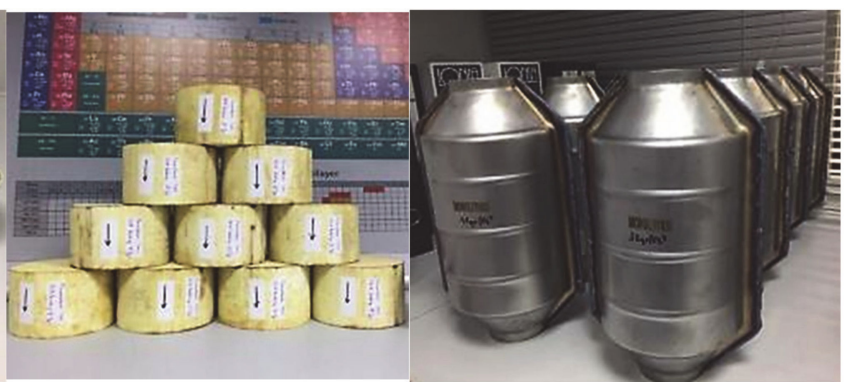

(b) (c)

Figure 1. (a) Preparation of large-scale PROMETHEUS catalysts (1 kg); (b) PROMETHEUS impregnated monoliths; (c) PROMETHEUS full-scale ready to install catalysts inside metallic canister.

In 1991 Bedford et al. presented and patented the synthesis of copper-based catalyst supported on Cerium oxide $\left(\mathrm{CeO}_{2}\right)$ and Aluminum oxide particles $\left(\mathrm{Al}_{2} \mathrm{O}_{3}\right)$ and its use in the catalytic flue gas treatment systems. The efficiency of the supported catalysts was measured under fresh (conversion: $76 \% \mathrm{HC}, 97 \% \mathrm{CO}, 2 \% \mathrm{NO}$ ) and aged conditions (conversion: $\sim 50 \%$ $\mathrm{HC}, \sim 60 \% \mathrm{CO}, \sim 2 \% \mathrm{NO}$ ) close to stoichiometric A/F ratio, 14.6 [25]. Later, a copper catalyst supported on $\mathrm{CeO}_{2}$, containing small amounts of one noble metal, as enhancer has been presented by Shore et al. Its use was limited to selective oxidation of carbon monoxide in gas streams containing high-concentration of hydrogen [26]. On the other hand, copper presents low activity regarding the reduction of NO in low temperatures. In 1999, Park et al. described the production of a series of catalysts consisting of mixed oxides (oxides of rare earth elements, alkalis, alkaline earth metals with transition metal oxides and noble metals) supported on zeolite catalyst (ZSM-5) [27]. As referred in the patent, the catalysts can be used for the selective catalytic reduction of $\mathrm{NO}_{\mathrm{x}}$ by using hydrocarbon (olefins or paraffins) as a reducing agent in oxygen excess (lean-burn conditions). More specific, by using copper ion exchanged $\mathrm{Cu}-\mathrm{ZSN}-5$ zeolite the conversion of nitrogen monoxide had reached an efficiency point of $(91.3 \%)$ at $420{ }^{\circ} \mathrm{C}$ [27]. Similarly, catalytic efficiency of $\mathrm{CuO} / \mathrm{CeO}_{2}$ and $\mathrm{CuO} / \gamma-\mathrm{Al}_{2} \mathrm{O}_{3}$ catalysts was measured for the $\mathrm{NO}+\mathrm{CO}$ reaction. Below $200{ }^{\circ} \mathrm{C}$ the loading amount of catalyst, the nature of the support and the dispersion of copper oxide species on the surface of the support have a strong effect on the catalytic activity of catalysts. Only after the temperature was increased to $300^{\circ} \mathrm{C}$, $\mathrm{NO}$ was completely converted to $\mathrm{N}_{2}$ over the catalysts [28].

PROMETHEUS is a low-cost catalyst for reducing of the three toxic pollutants present in gasoline engine flue gases; $\mathrm{CO}, \mathrm{C}_{\mathrm{x}} \mathrm{H}_{\mathrm{y}}$ and $\mathrm{NO}_{\mathrm{x}}$, which consists of copper $(\mathrm{Cu})$ and two noble metals, palladium (Pd) and rhodium ( $\mathrm{Rh}$ ). In the present work, the catalytic activity of PROMETHEUS full-scale catalysts towards the oxidation of $\mathrm{CO}$ and $\mathrm{CH}_{4}$ and the reduction of NO is presented and discussed extensively. The synthesis and characterization of the catalyst have already been studied and published in our previous work [24]. Furthermore, commercial three-way catalysts which represent the performance of catalysts suitable for Euro III (catalyst OEM III), Euro IV (catalyst OEM IV) and Euro V/VI (catalyst OEM V/VI) protocol, have been used as benchmark. Their catalytic performance has been studied for comparison reasons. The two full-scale PROMETHEUS monolithic catalysts with loading $5 \mathrm{~g} \mathrm{PGMs} / \mathrm{ft}^{3}$ and $15 \mathrm{~g}$ PGMs $/ \mathrm{ft}^{3}$ correspond to EURO III catalyst and EURO IV/V/VI, respectively. The catalytic experiments took place on an in-house Synthetic Gas Bench apparatus (SGB) under selected simulated gasoline engine exhaust conditions under both reducing $(\lambda=0.99)$ and oxidizing $(\lambda=1.03)$ conditions. All the catalysts were tested after hydrothermal ageing treatment at $1050{ }^{\circ} \mathrm{C}$ for $4 \mathrm{~h}$ under $10 \% \mathrm{H}_{2} \mathrm{O}$ in air flow. Finally, both fresh and aged samples of the tested PROMETHEUS catalyst presented excellent catalytic activity and characteristics similar or even improved compared with the commercially available catalysts bearing higher loading on PGMs. 


\section{Materials and Methods}

\subsection{Tested Catalysts}

PROMETHEUS catalytic washcoat production which consists of $2 \mathrm{wt} \% \mathrm{Cu}, \mathrm{Pd}$ and $\mathrm{Rh}$ nanoparticles supported over $\mathrm{Ce}_{0.68} \mathrm{Zr}_{0.32} \mathrm{O}_{2}$ inorganic carrier (PROM2) and its deposition on monolithic cordierites achieving the production of full-scale PROMETHEUS catalysts have been presented in our previous work [24]. In more details, for the production of full-scale PROMETHEUS monolithic catalysts, ceramic cordierite-based monoliths (Mg, $\mathrm{Fe})_{2} \mathrm{Al}_{4} \mathrm{Si}_{5} \mathrm{O}_{18}$ ) were impregnated to produce full scale catalysts ready to be installed to vehicles.

Initially, the bulk characteristics of ceramic monolith were determined followed by drying at $90{ }^{\circ} \mathrm{C}$. Then, an aqueous slurry containing the appropriate amount of catalytic powder PROM2 and $\gamma-\mathrm{Al}_{2} \mathrm{O}_{3}$ boehmite (SASOL, GmbHbinder, Hamburg, Germany) was prepared at room temperature under stirring by adjusting the $\mathrm{pH}$ value at $\mathrm{pH} 7$ units with $25 \%$ aq. $\mathrm{NH}_{4} \mathrm{OH}$ buffer solution (Kalogeropoulos Industrial, Piraeus, Greece). The monolith was impregnated in the produced slurry repeatedly and dried at $90{ }^{\circ} \mathrm{C}$ between the impregnation repetitions in different orientation each time, in order to avoid capillary forces phenomena in the cells of the cordierite. The impregnated monolith was finally calcinated at $500{ }^{\circ} \mathrm{C}$ for $1 \mathrm{~h}$ (heating ramp. $10^{\circ} \mathrm{C} \cdot \mathrm{min}^{-1}$ ) and then blown with air, in order for the non-coated particles to be removed. The metal loading of the monolith was determined by the weight of the monolith before and after the impregnation. In case the final weight of coated monolith was not the desired one, the wash coating step was repeated. For this study, catalytic activity experiments took place with samples obtained from the full-scale catalyst, including catalytic nanoparticles, washcoat and the substrate of the cordierite (Figure 2). This approach was followed in order for the catalytic measurement results to be comparable to the benchmark original catalysts.

Sample from full catalyst embedded on cordierite

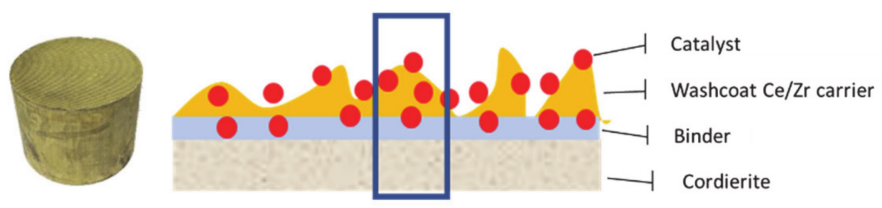

Sample from catalyst on $\mathrm{Ce} / \mathrm{Zr}$ substrate

Figure 2. Configurations of the samples used on this study (full scale catalyst).

Herein, the two produced full-scale PROMETHEUS catalysts with $5 \mathrm{~g}$ PGMs $/ \mathrm{ft}^{3}$ and $15 \mathrm{~g}$ PGMs $/ \mathrm{ft}^{3}$ loading, named 5PROM2 and 15PROM2, respectively and the commercial catalysts OEM III (VW Group Polo), OEM IV (VW Group Polo) and OEM V/VI (Renault Meganne) used as benchmark (Figure 3), were tested and evaluated towards the oxidation of $\mathrm{CO}$ and $\mathrm{CH}_{4}$ and reduction of $\mathrm{NO}$ in the synthetic gas bench apparatus. The commercial TWCs were selected as benchmark catalysts and represent the performance of a catalyst suitable for Euro III (catalyst OEM III), Euro IV (catalyst OEM IV) and Euro V/VI (catalyst OEM V/VI) protocol. In addition, PROMETHEUS catalysts incorporate 85\% less PGMs compared to the above original catalysts; 5PROM2 for EURO III applications (compared with $32 \mathrm{~g} / \mathrm{ft}^{3}$ PGMs of the original catalyst) and 15PROM2 for EURO IV / V / VI applications (compared to more than $100 \mathrm{~g} / \mathrm{ft}^{3}$ PGMs of the original catalyst). All the full-scale catalysts (PROMETHEUS full scale catalysts and commercial catalysts) were characterized by X-ray Fluorescence Spectroscopy in order the existence and subsequently the concentration of PGMs (Pt, Pd, Rh) and copper to be determined prior to the catalytic experiments and by Optical Microscopy for the structure analysis. 


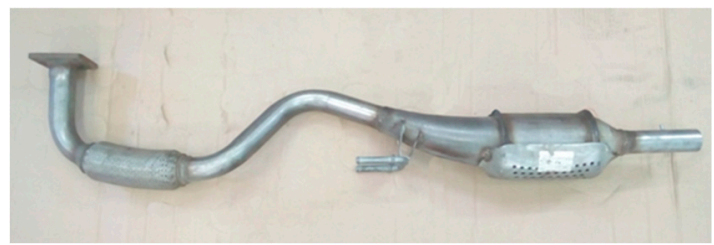

(a)

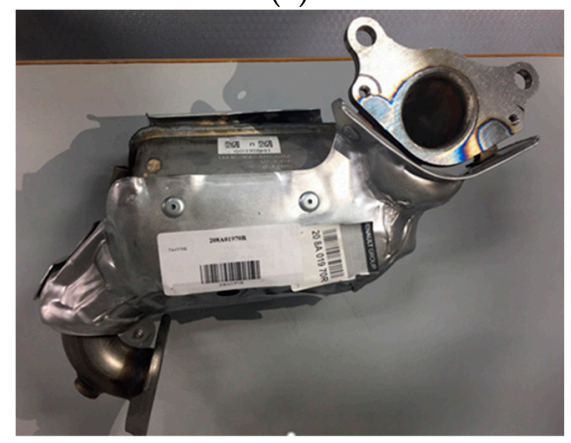

(c)

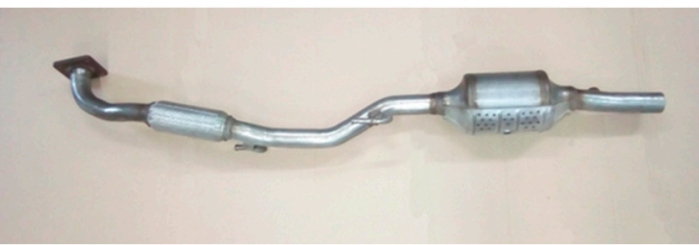

(b)

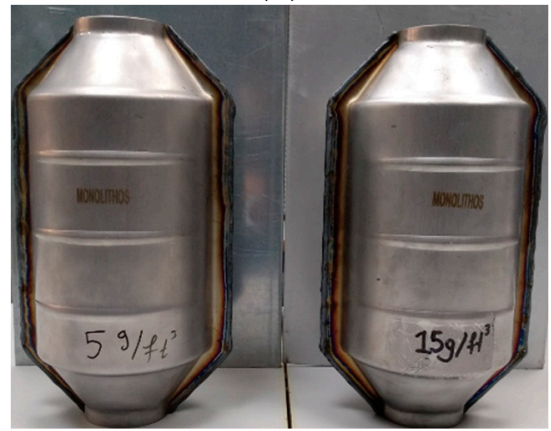

(d)

Figure 3. (a) OEM EURO III exhaust spare part for VW Polo 1.4 Lt; (b) OEM EURO IV exhaust spare part for VW Polo $1.4 \mathrm{Lt}$; (c) OEM EURO V/VI exhaust spare part for Renault Meganne 1.2 Lt Turbo; (d) PROMETHEUS Full Scale Monolithic Catalysts $\left(5-15 \mathrm{~g} / \mathrm{ft}^{3}\right)$.

\subsection{X-ray Fluorescence Spectroscopy}

Prior to the catalytic experiments X-ray fluorescence spectroscopy (XRF, Vanta Olympus, Waltham, MA, USA) was applied in catalysts samples (PROMETHEUS full scale catalysts and commercial catalysts) for qualitative and quantitative analysis (Table 1). As seen from Table 1, commercial catalysts OEM III, OEM IV and OEM V/VI consist of PGMs (Pd and Rh), while full-scale PROMETHEUS catalysts consist of PGMs (Pd and Rh) and $\mathrm{Cu}$. In more detail, the full-scale catalysts were grinded to pieces and then subjected to milling and sieved in order for particle size $<125 \mu \mathrm{m}$ powder to be obtained (Planetary Ball Mill Machine LITH-XQM-0.4, Lith Machine Ltd., Xiamen, Fujian, China). Finally, the obtained powder was dried at $120^{\circ} \mathrm{C}$ for $2 \mathrm{~h}$. The metal content of the catalysts was determined by the analysis of powder received by the corresponding catalysts. For the analysis, the samples were prepared in the form of pressed powder inside polyethylene cups where the appropriate amount of catalyst powder was found to be approximately $5 \mathrm{~g}$ for each sample. The analysis of the samples was carried out by measuring each sample with 10 repeated scans, of $90 \mathrm{~s}$ each. In order for higher accuracy to be obtained in XRF measurement, the XRF instrument (Vanta Olympus, Waltham, MA, USA) was calibrated for each metal separately, additionally to the internal calibration of the instrument. In the case of precious metals (Pt, $\mathrm{Pd}$ and $\mathrm{Rh}$ ), thirteen automotive catalyst samples with varied metal concentration were used for calibration. On the other hand, in case of copper, commercial samples with known metal concentrations were used for calibration (OREAS Pty Ltd. CRMs, Bayswater, North Vic, Australia). The nominal concentration value was already measured by ICP-MS method. Pt has been calibrated in the loading range of 600-2800 ppm, Pd in the loading range of 1270-2730 ppm, Rh in the loading range of 230-330 ppm and $\mathrm{Cu}$ in the loading range of $0.07-12 \%$ [29]. 
Table 1. PGMs and copper loading for commercial Three-Way Catalysts TWCs (benchmark catalysts) and PROMETHEUS full scale catalysts produced.

\begin{tabular}{|c|c|c|c|c|c|c|c|c|}
\hline Abbreviation & Company & Model & Motor & Euro & $\begin{array}{c}\mathrm{Cu} \\
\text { (ppm/\%wt.) }\end{array}$ & $\begin{array}{c}P d \\
\text { (ppm/\%wt.) }\end{array}$ & $\begin{array}{c}\text { Rh } \\
\text { (ppm/\%wt.) }\end{array}$ & $\begin{array}{l}\text { PGM Loading } \\
\qquad\left(\mathrm{g} / \mathrm{ft}^{3}\right)^{1}\end{array}$ \\
\hline 5PROM2 & MONOLITHOS & Universal & Up to $1.6 \mathrm{Lt}$ & III & $\begin{array}{c}820 \\
0.082\end{array}$ & $\begin{array}{c}280 \\
0.028\end{array}$ & $\begin{array}{c}40 \\
0.004\end{array}$ & 5 \\
\hline OEM III & VW Group & Polo & $1.4 \mathrm{Lt}$ & III & - & $\begin{array}{c}1392 \\
0.1392\end{array}$ & $\begin{array}{c}295 \\
0.0295\end{array}$ & 32 \\
\hline OEM IV & VW Group & Polo & $1.4 \mathrm{Lt}$ & IV & - & $\begin{array}{c}4872 \\
0.4872\end{array}$ & $\begin{array}{c}306 \\
0.0306\end{array}$ & 108 \\
\hline OEM V/VI & Renault & Meganne & 1.2 Lt turbo & $\mathrm{V} / \mathrm{VI}$ & - & $\begin{array}{c}5642 \\
0.5642\end{array}$ & $\begin{array}{c}471 \\
0.0471\end{array}$ & 101 \\
\hline 15PROM2 & MONOLITHOS & Universal & Up to $1.6 \mathrm{Lt}$ & VI & $\begin{array}{l}2320 \\
0.232\end{array}$ & $\begin{array}{c}780 \\
0.078\end{array}$ & $\begin{array}{c}110 \\
0.011\end{array}$ & 15 \\
\hline
\end{tabular}

${ }^{1}$ mass and geometric volume of the monolithic were calculated before crushing.

\subsection{Optical Microscopy}

The sample for the structure analysis of the catalysts was prepared according to the following procedure, a piece of each catalyst in shape of carrot (dimensions: $\mathrm{d}: 4.4 \mathrm{~cm}$, 1: $7.6 \mathrm{~cm}$ ) was extracted from the main cordierite (Figure 4) and then each sample has been cross-sectionally cut so that the monolith cells can be observed. Optical microscopy, using a metallurgical microscope by AmScope (ME520 series, Irvine, CA, USA) equipped with a microscope digital camera $14 \mathrm{MP}$ ultrafine color was used. Each sample was placed under the objective lenses in order to be moved in the vertical direction to focus and obtain a resolution suitable for measuring the thickness of the wash-coat. In Figure 5, the optical microscopy cross-section images of the benchmark catalysts OEM III, OEM IV, OEM $\mathrm{V} / \mathrm{VI}$ and the PROMETHEUS Full Scale monolithic catalysts 5PROM2 and 15PROM2 at $5 \times$ optical zoom are presented.

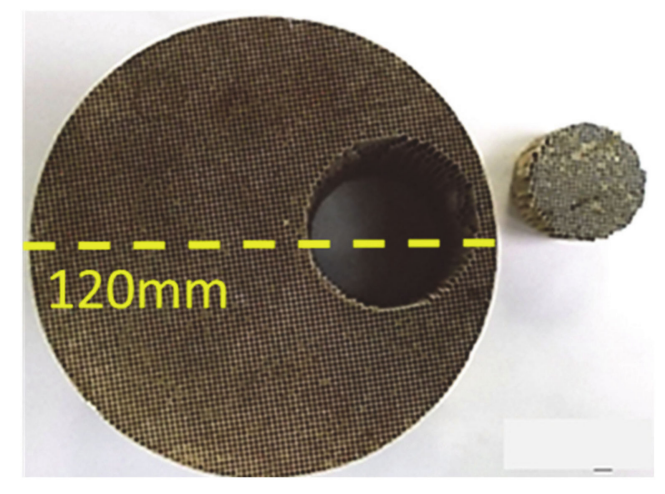

Figure 4. Carrot extraction from 15PROM2 catalyst.

As shown, in case of OEM III, only one coating layer can be distinguished on the walls of the cordierite matrix; corresponding to the catalyst distributed on the wash coat, having thickness of approximately 50-120 $\mu \mathrm{m}$ (Figure 5a), while for OEM IV catalyst two coating layers can be distinguished on the walls of the cordierite matrix; a thin internal layer covering mostly the "dead volume" at the corner zones and a second thin catalyst layer on top of the first one. Both coatings seem to be uniform, with thickness of approximately 70-100 $\mu \mathrm{m}$ (Figure 5b). In the examined sample of the primary catalyst OEM V/VI the thickness of the catalytic surface layer was approximately $20-70 \mu \mathrm{m}$, while the interlayer is approximately 10-20 $\mu \mathrm{m}$ (Figure 5c). On the other hand, in the sample of the second catalyst OEM V/VI the thickness of the catalytic surface layer is approximately 20-100 $\mu \mathrm{m}$, while the interlayer is approximately $10-50 \mu \mathrm{m}$ (Figure $5 \mathrm{~d}$ ). Finally, in the piece of 5PROM2 $\left(5 \mathrm{~g} / \mathrm{ft}^{3}\right)$ and 15PROM2 $\left(15 \mathrm{~g} / \mathrm{ft}^{3}\right)$ catalysts the thickness of the catalytic surface layer is 
20-50 $\mu \mathrm{m}$ (Figure 5e) and 50-100 $\mu \mathrm{m}$ (Figure 5f), respectively, which proves that are similar to the corresponding commercial catalysts.

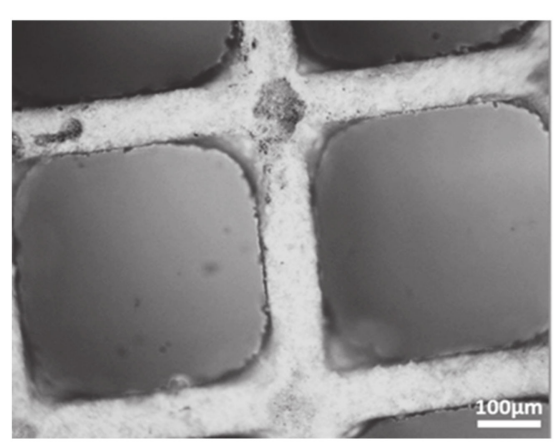

(a)

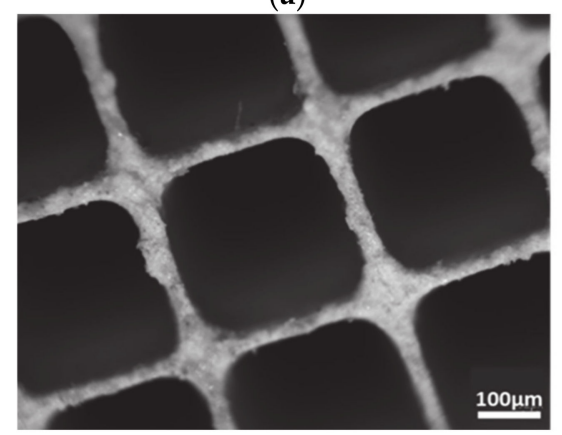

(c)

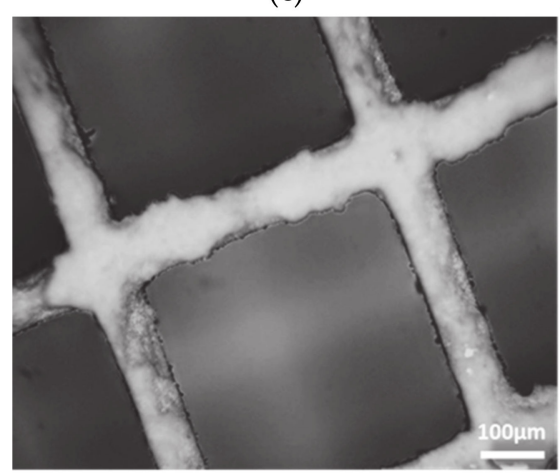

(e)

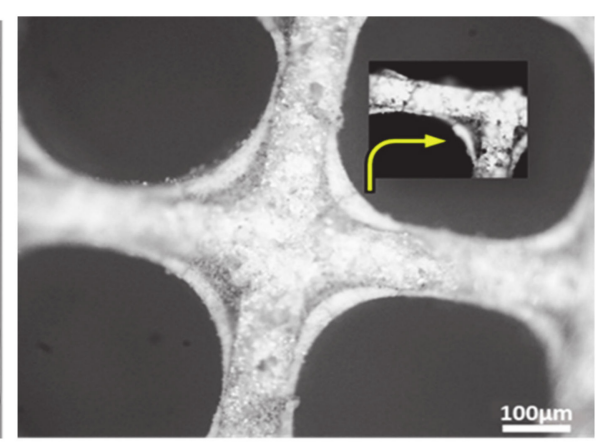

(b)

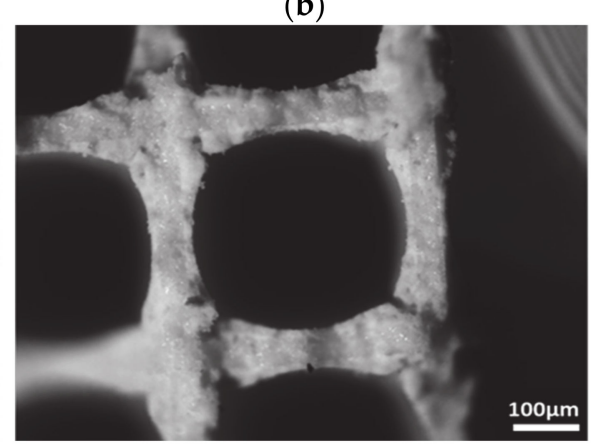

(d)

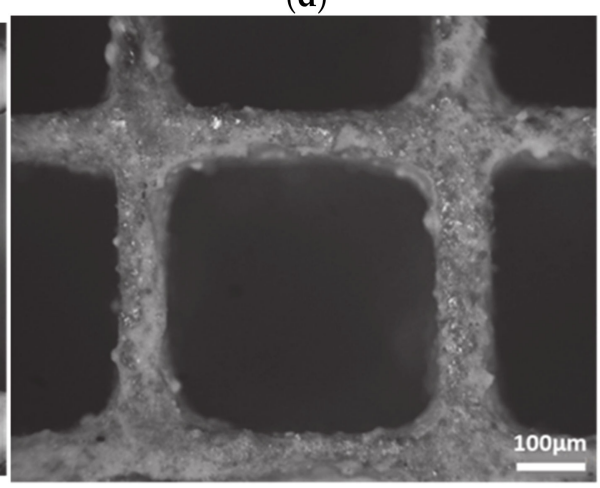

(f)

Figure 5. Optical microscopy cross-section images $(5 \times)$ of the catalysts: (a) OEM III; (b) OEM V/VI (inlet image $10 \times$ ); (c) Primary catalyst of OEM V/VI; (d) Second catalyst of OEM V/VI; (e) 5PROM2; (f) 15PROM2.

\subsection{Synthetic Gas Bench (SGB)}

The catalytic activity of both produced and commercial catalysts was tested in an in-house synthetic gas bench (SGB) apparatus. The lab-scale SGB device was designed and built in MONOLITHOS (Athens, Greece) premises. A schematic representation of the experimental setup is shown in Figure 6, where three regions can be distinguished: the gas feed, the reactor and the gas analysis. The gas feed region contains the reactant gases (certified standards) of Air, $\mathrm{NO}, \mathrm{CO}_{2}, \mathrm{CH}_{4}, \mathrm{CO}$ (each gas was diluted in $\mathrm{N}_{2}$ ) and pure $\mathrm{N}_{2}$ for balance, the mass flow controllers for mixing the gases and the thermostated water saturator for steam introduction to the gas mixture. The reactor region contains a thermostated furnace and a U-shaped quartz reactor (Figure 7), while the gas analysis region contains the water trapping system and the gas analysis system. 


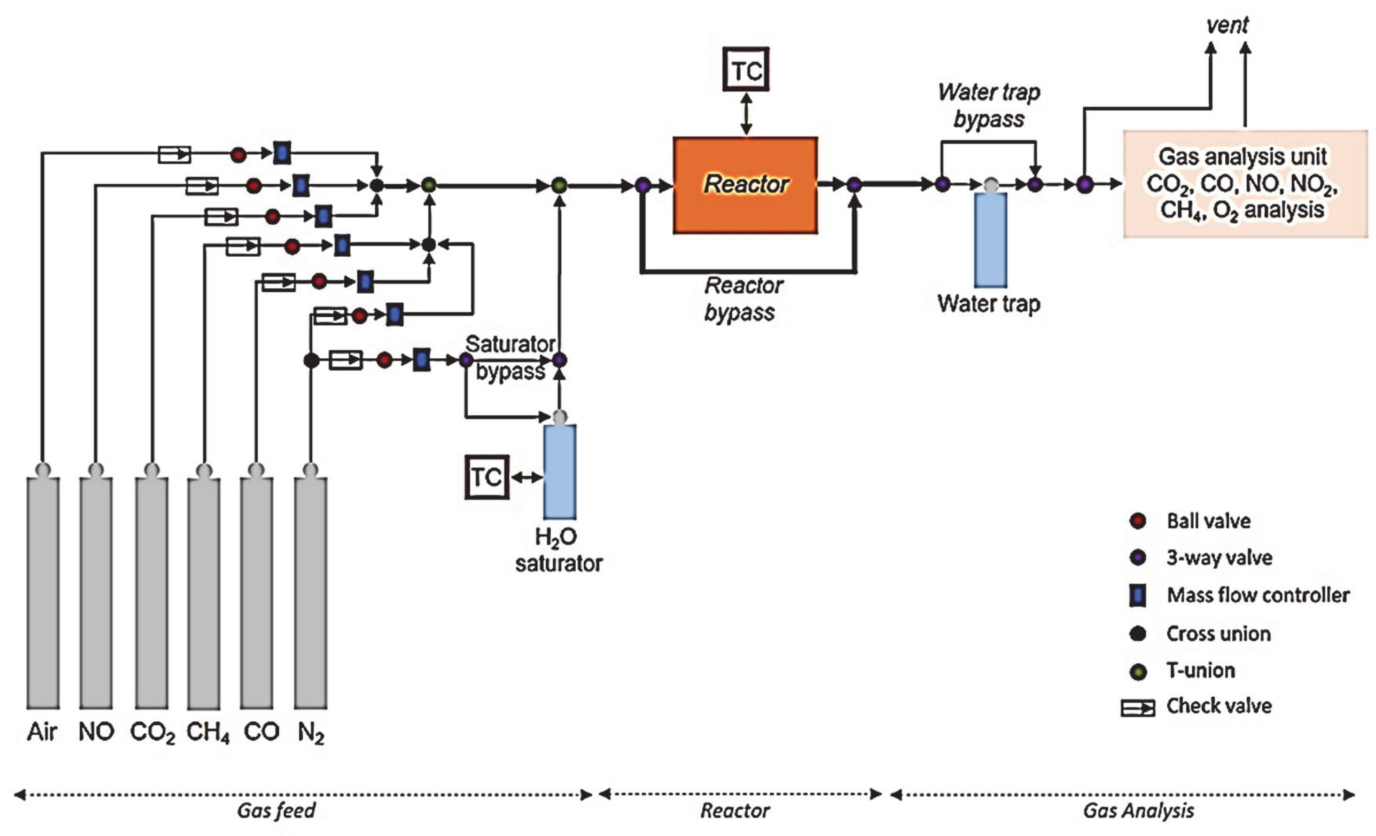

Figure 6. Schematic representation of the experimental setup used for the catalytic activity test of catalysts.

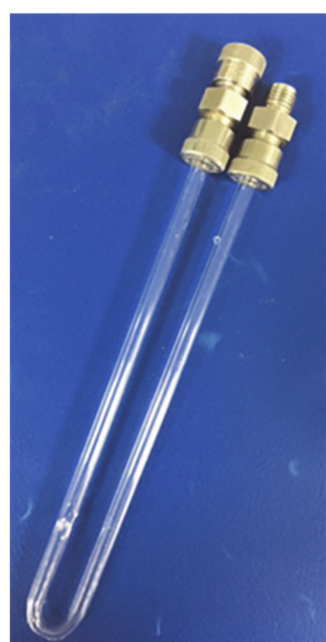

(a)

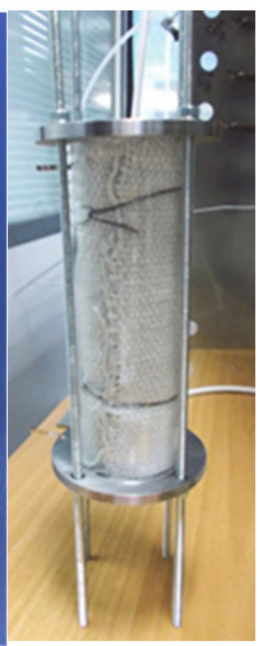

(b)

Figure 7. (a) U-shaped quartz reactor for activity testing of catalyst powders; (b) tube experimental electrical furnace.

Moreover, in Figure 8, a picture of the experimental setup is presented, where the reactor furnace stands on the right of the control panel. The gas analyzer (GA-200 PVT, HNL Ltd., Mumbai, India) enables the simultaneous analysis of $\mathrm{CO}_{2}, \mathrm{CO}, \mathrm{O}_{2}, \mathrm{NO}, \mathrm{CH}_{4}$ and $\mathrm{NO}_{2}$ and is used downstream the reactor region. Need to be mentioned that the formation of $\mathrm{N}_{2} \mathrm{O}$ was found to be in low selectivity $<50 \mathrm{ppm}$ in the range temperature of $250-300{ }^{\circ} \mathrm{C}$ and as a result this product has not been discussed in the present study. The analysis of gases is carried out through an automated sampling system for a fixed sampling time.

The experimental setup enables fast on-site performance screening of catalyst powders under selected simulated gasoline engine exhaust conditions. It should be noted that $\mathrm{CH}_{4}$ was used for the simulation of mixture in a real exhaust gas of a petrol engine as it is the major constituent of total hydrocarbon emissions (THC) [30]. As a result, catalytic activity tests were performed both under reducing $(\lambda=0.99)$ and oxidizing conditions $(\lambda=1.03)$ (lambda sensor $\lambda=\mathrm{A} / \mathrm{F}$; A: air, F: Fuel), in the temperature range between $100-525^{\circ} \mathrm{C}$. In both conditions, the total flow rate was $300 \mathrm{sccm}$, which corresponded to a gas hourly 
space velocity of $50.000 \mathrm{~h}^{-1}$. The composition of the two examined gas mixtures applied in the catalytic activity tests are summarized in Table 2.

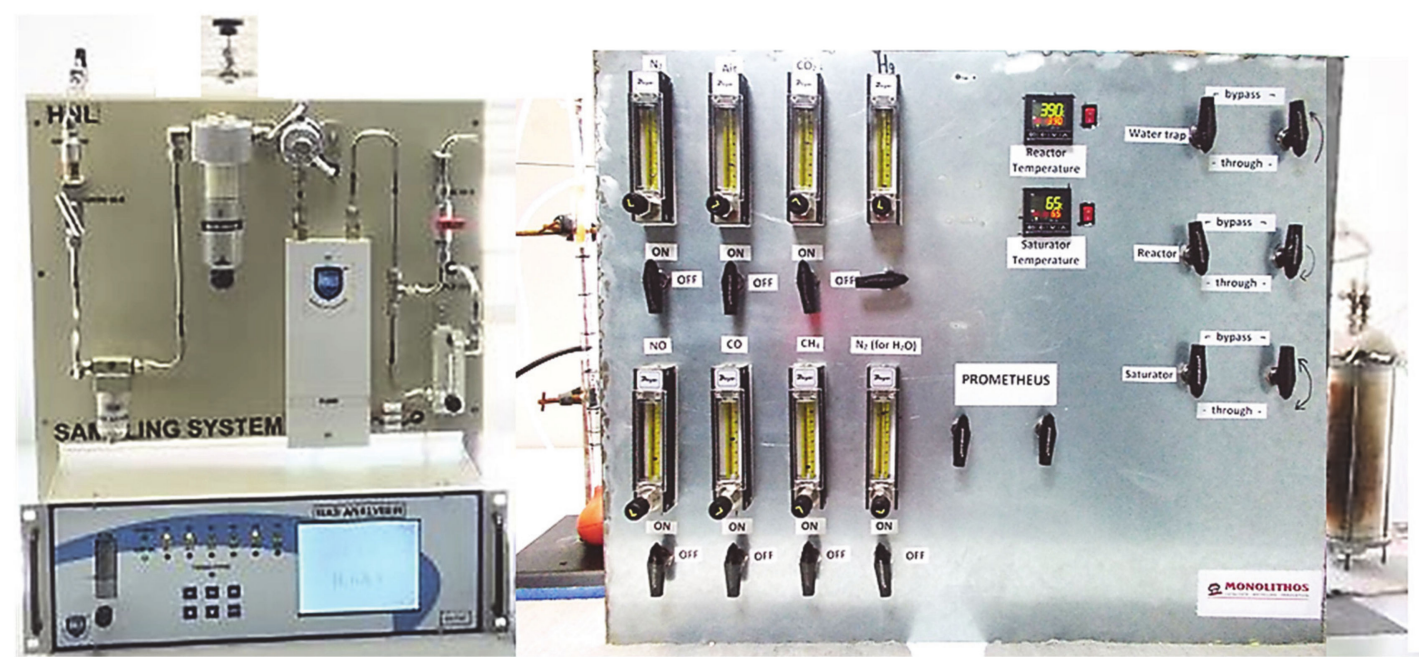

Figure 8. Catalyst activity lab-scale testing setup (SGB apparatus).

Table 2. Selected gas mixtures concentrations for $\lambda=0.99$ and $\lambda=1.03$.

\begin{tabular}{ccccccc}
\hline & \multicolumn{5}{c}{ Gas Component } \\
\cline { 2 - 6 }$\lambda$ Factor Values & $\begin{array}{c}\mathbf{C O} \\
\mathbf{( \% )}\end{array}$ & $\begin{array}{c}\mathbf{C O}_{\mathbf{2}} \\
\mathbf{( \% )}\end{array}$ & $\begin{array}{c}\mathbf{O}_{\mathbf{2}} \\
\mathbf{( \% )}\end{array}$ & $\begin{array}{c}\mathbf{N O} \\
(\mathbf{p p m})\end{array}$ & $\begin{array}{c}\mathbf{C H}_{\mathbf{4}} \mathbf{1} \\
(\mathbf{p p m})\end{array}$ & $\begin{array}{c}\mathbf{H}_{\mathbf{2}} \mathbf{O} \\
\mathbf{( \% )}\end{array}$ \\
\hline $\begin{array}{c}\text { Rich-burn conditions } \\
\lambda=0.99\end{array}$ & 1 & 12 & 0.91 & 800 & 2500 & 10 \\
$\begin{array}{c}\text { Lean-burn conditions } \\
\lambda=1.03\end{array}$ & 1 & 12 & 0.95 & 800 & 2500 & 10 \\
\hline
\end{tabular}

${ }^{1} \mathrm{CH}_{4}$ was used for the simulation of mixture in a real exhaust gas of a petrol engine.

\subsection{Catalyst Ageing Procedure}

Catalyst ageing was performed in all presented herein catalysts according to certified protocol. According to the protocol, each sample was heated up to $1050^{\circ} \mathrm{C}$ for $4 \mathrm{~h}$ under $10 \% \mathrm{H}_{2} \mathrm{O}$ air flow. A high temperature calcination furnace was used equipped with an atmospheric air electric pump for air introduction to the heating chamber. Upstream the furnace, the air stream was passing through a thermostated water saturator operating at $46{ }^{\circ} \mathrm{C}$, for the introduction of $10 \% \mathrm{H}_{2} \mathrm{O}$ in air mixture into the furnace chamber. Finally, catalytic activity tests were performed both under reducing and oxidizing conditions $\left(\lambda=0.99\right.$ and $\lambda=1.03$, respectively), in the temperature range between 100 and $550{ }^{\circ} \mathrm{C}$. In both conditions the total flow rate was $300 \mathrm{sccm}$, which corresponded to a gas hourly space velocity of $50,000 \mathrm{~h}^{-1}$. The composition of the two examined gas mixtures applied in the catalytic activity tests are summarized in Table 2 .

\section{Results}

\subsection{Catalytic Activity of Fresh Catalysts}

Initially, the catalytic efficiency of fresh commercial-benchmark and produced PROMETHEUS catalysts were tested in the synthetic gas bench (SGB) apparatus, simulating the operation of an internal combustion engine. The experimental conditions were selected based on certified testing protocol and were kept constant in all experiments. Catalytic activity tests were performed under both reducing and oxidizing conditions $\left(\lambda=0.99\right.$ and $\lambda=1.03$, respectively), in the temperature range between 100 and $550{ }^{\circ} \mathrm{C}$. The composition of the two examined gas mixtures applied in each condition are sum- 
marized in Table 2. The fresh samples of catalysts are expected to show the best catalytic performance, as they represent a brand-new catalyst of zero mileage.

3.1.1. Catalytic Efficiency Comparison of OEM III with 5PROM2 Full Scale Catalyst (84.4\% Substitution of PGMs with Copper NanoParticles)

In Figure 9 the light-off curves (conversion vs. temperature) for $\mathrm{CO}$ and $\mathrm{CH}_{4}$ oxidation and for NO reduction in both rich- and lean-burn catalytic conditions $(\lambda=0.99$ and $\lambda=1.03)$ over the fresh commercial catalyst OEM III and PROMETHEUS full scale monolithic catalyst 5PROM2 are presented. Important activity indication values for catalyst characterization for rich- and lean-burn catalytic conditions are summarized in Tables 3 and 4, respectively.

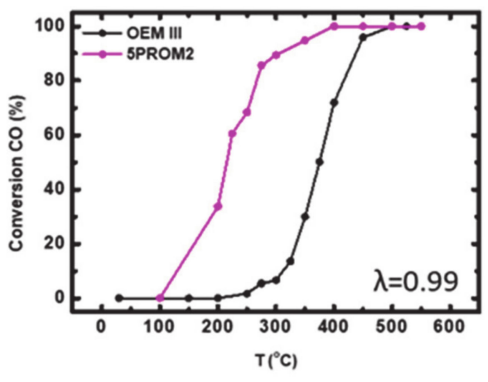

(a)

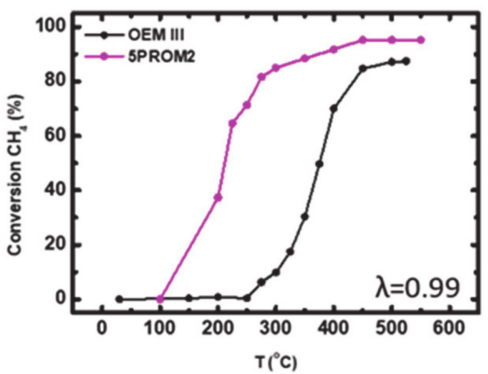

(b)

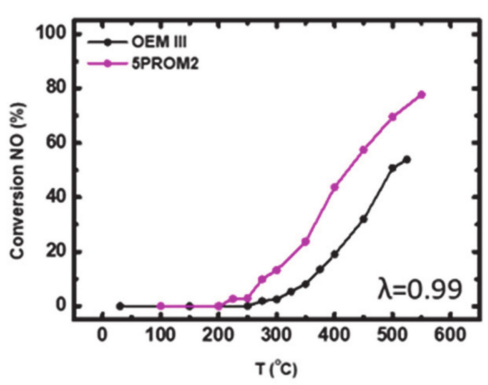

(c)

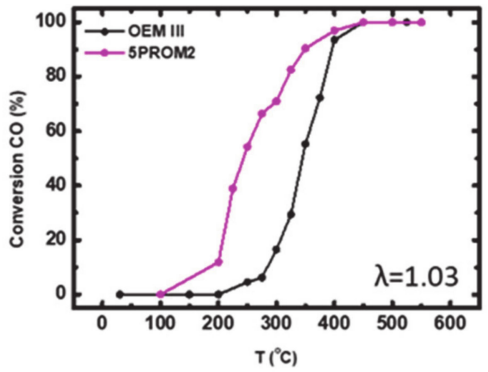

(d)

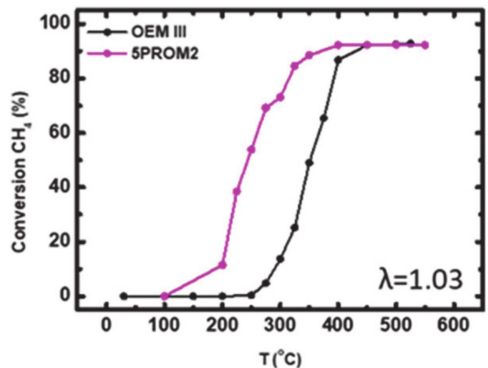

(e)

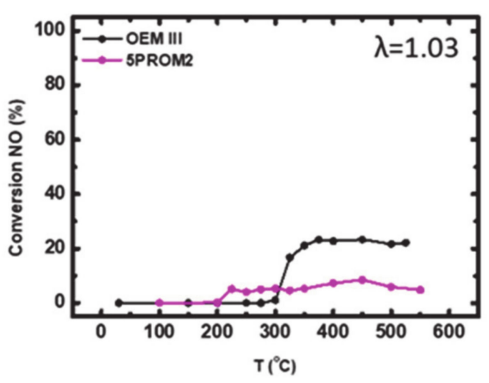

(f)

Figure 9. Light-off curves for the (\%) conversion of: (a) $\mathrm{CO}$; (b) $\mathrm{CH}_{4}$; (c) $\mathrm{NO}$ under rich-burn conditions ( $\lambda=0.99) ;(\mathbf{d}) \mathrm{CO} ;(\mathbf{e}) \mathrm{CH}_{4} ;(\mathbf{f}) \mathrm{NO}$ under lean-burn conditions $(\lambda=1.03)$ over commercial catalyst OEM III and PROMETHEUS Full Scale monolithic catalyst 5PROM2.

Table 3. Comparison of tested catalysts OEM III and 5PROM2 under rich-burn conditions $(\lambda=0.99)$.

\begin{tabular}{|c|c|c|c|c|c|c|c|c|c|c|c|c|}
\hline \multirow[b]{2}{*}{ Catalyst } & \multicolumn{4}{|c|}{ CO Oxidation } & \multicolumn{4}{|c|}{$\mathrm{CH}_{4}$ Oxidation } & \multicolumn{4}{|c|}{ NO Reduction } \\
\hline & $\begin{array}{c}\mathrm{T}_{50} \\
\left({ }^{\circ} \mathrm{C}\right)\end{array}$ & $\begin{array}{c}\mathrm{T}_{90} \\
\left({ }^{\circ} \mathrm{C}\right)\end{array}$ & $\begin{array}{c}\mathrm{T}_{99} \\
\left({ }^{\circ} \mathrm{C}\right)\end{array}$ & $\begin{array}{c}\text { Max. } \\
\text { Efficiency } \\
(\%)\end{array}$ & $\begin{array}{c}\mathrm{T}_{50} \\
\left({ }^{\circ} \mathrm{C}\right)\end{array}$ & $\begin{array}{c}\mathrm{T}_{90} \\
\left({ }^{\circ} \mathrm{C}\right)\end{array}$ & $\begin{array}{c}\mathrm{T}_{99} \\
\left({ }^{\circ} \mathrm{C}\right)\end{array}$ & $\begin{array}{c}\text { Max. } \\
\text { Efficiency } \\
(\%)\end{array}$ & $\begin{array}{c}\mathrm{T}_{50} \\
\left({ }^{\circ} \mathrm{C}\right)\end{array}$ & $\begin{array}{c}\mathrm{T}_{90} \\
\left({ }^{\circ} \mathrm{C}\right)\end{array}$ & $\begin{array}{c}\mathrm{T}_{99} \\
\left({ }^{\circ} \mathrm{C}\right)\end{array}$ & $\begin{array}{c}\text { Max. } \\
\text { Efficiency } \\
(\%)\end{array}$ \\
\hline OEM III & 375 & 437 & 490 & $100 \%$ & 375 & - & - & $87 \%$ & 500 & - & - & $54 \%$ \\
\hline 5PROM2 & 215 & 306 & 388 & $100 \%$ & 212 & 375 & - & $95 \%$ & 425 & - & - & $78 \%$ \\
\hline
\end{tabular}


Table 4. Comparison of tested catalysts OEM III and 5PROM2 under lean-burn conditions $(\lambda=1.03)$.

\begin{tabular}{|c|c|c|c|c|c|c|c|c|c|c|c|c|}
\hline \multirow[b]{2}{*}{ Catalyst } & \multicolumn{4}{|c|}{ CO Oxidation } & \multicolumn{4}{|c|}{$\mathrm{CH}_{4}$ Oxidation } & \multicolumn{4}{|c|}{ NO Reduction } \\
\hline & $\begin{array}{c}\mathrm{T}_{50} \\
\left({ }^{\circ} \mathrm{C}\right)\end{array}$ & $\begin{array}{c}\mathrm{T}_{90} \\
\left({ }^{\circ} \mathrm{C}\right)\end{array}$ & $\begin{array}{c}\mathrm{T}_{99} \\
\left({ }^{\circ} \mathrm{C}\right)\end{array}$ & $\begin{array}{c}\text { Max. } \\
\text { Efficiency } \\
(\%)\end{array}$ & $\begin{array}{c}\mathrm{T}_{50} \\
\left({ }^{\circ} \mathrm{C}\right)\end{array}$ & $\begin{array}{c}\mathrm{T}_{90} \\
\left({ }^{\circ} \mathrm{C}\right)\end{array}$ & $\begin{array}{c}\mathrm{T}_{99} \\
\left({ }^{\circ} \mathrm{C}\right)\end{array}$ & $\begin{array}{c}\text { Max. } \\
\text { Efficiency } \\
(\%)\end{array}$ & $\begin{array}{c}\mathrm{T}_{50} \\
\left({ }^{\circ} \mathrm{C}\right)\end{array}$ & $\begin{array}{c}\mathrm{T}_{90} \\
\left({ }^{\circ} \mathrm{C}\right)\end{array}$ & $\begin{array}{c}\mathrm{T}_{99} \\
\left({ }^{\circ} \mathrm{C}\right)\end{array}$ & $\begin{array}{c}\text { Max. } \\
\text { Efficiency } \\
(\%)\end{array}$ \\
\hline OEM III & 345 & 390 & 440 & $100 \%$ & 350 & 420 & - & $93 \%$ & - & - & - & $23 \%$ \\
\hline 5PROM2 & 240 & 350 & 430 & $100 \%$ & 240 & 375 & - & $92 \%$ & - & - & - & $8 \%$ \\
\hline
\end{tabular}

As mentioned above, the catalysts OEM III and 5PROM2 are suitable for Euro III emission standard. According to the results in rich-burn conditions $(\lambda=0.99)$ the two catalysts were active at $\mathrm{T}>260{ }^{\circ} \mathrm{C}$ and $\mathrm{T}>200{ }^{\circ} \mathrm{C}$, respectively. It is proved that $\mathrm{CO}$ oxidation efficiency reached $\sim 100 \%$ in each case (Figure $9 \mathrm{a}$ ), while $\mathrm{CH}_{4}$ oxidation efficiency was limited to $87 \%$ for OEM III and 95\% for 5PROM2 catalyst (Figure $9 \mathrm{~b}$ ). Furthermore, NO reduction reached $54 \%$ at $\sim 525{ }^{\circ} \mathrm{C}$ for OEM III catalyst and $78 \%$ at $\mathrm{T} \sim 550{ }^{\circ} \mathrm{C}$ for 5 PROM2 catalyst (Figure 9c). On the other hand, under lean-burn conditions $(\lambda=1.03)$ catalysts were active at $\mathrm{T}>270{ }^{\circ} \mathrm{C}$ and $\mathrm{T}>200^{\circ} \mathrm{C}$, respectively. The $\mathrm{CO}$ oxidation efficiency reached $\sim 100 \%$ over the two catalysts (Figure $9 \mathrm{~d}$ ), while $\mathrm{CH}_{4}$ oxidation reached $93 \%$ for OEM III and $92 \%$ for PROMETHEUS catalyst 5PROM2 (Figure 9e). Finally, NO reduction was low (OEM III: 23\%, 5PROM2: 8\%) possibly due to surface oxidation of Rh nanoparticles of the catalysts (Figure 9f). As a result, comparing the catalytic efficiency of the two catalysts, PROMETHEUS full scale monolithic catalyst 5PROM2, presents similar and in some cases higher catalytic activity in lower light-off temperatures (T50 and T90) compared to the commercial catalyst OEM III by significantly substitution of PGMs (Pd and Rh) with copper nanoparticles. Especially, in case of $\mathrm{CO}$ and $\mathrm{CH}_{4}$ conversion (\%), 5PROM2 catalyst presents much lower values of T50 and T90 in both rich-burn and Lean-burn conditions with similar yield value (\%) to OEM III catalyst.

3.1.2. Catalytic Efficiency Comparison of OEM IV and OEM V/VI with 15PROM2 Full Scale Catalyst (85.1\% Substitution of PGMs with Copper NanoParticles)

The two commercial catalysts OEM IV, OEM V/VI and the produced full-scale PROMETHEUS monolithic catalyst, named 15PROM2 were also tested under both richburn $(\lambda=0.99)$ and lean-burn $(\lambda=1.03)$ conditions for the abatement of $\mathrm{CO}, \mathrm{CH}_{4}$ and NO. The corresponding light-off curves are shown in Figure 10 and catalytic activity values are presented in Tables 5 and 6, respectively.

Under rich-burn conditions OEM IV, OEM V/VI and 15PROM2 catalysts were active at $\mathrm{T}>250, \mathrm{~T}>200$ and $\mathrm{T}>190{ }^{\circ} \mathrm{C}$, respectively. CO oxidation efficiency reached $100 \%$ in each case, while $\mathrm{CH}_{4}$ oxidation efficiency was reached 87,88 and $87 \%$, respectively (Figure 10a,b). It is worth noting that the reduction efficiency of NO was recorded at $96 \%$ $\left(\mathrm{T} \sim 320^{\circ} \mathrm{C}\right.$ ) over OEM IV catalyst, at $96 \%\left(\mathrm{~T}>350^{\circ} \mathrm{C}\right)$ over OEM V/VI catalyst and $96 \%$ (T $\sim 410^{\circ} \mathrm{C}$ ) over 15PROM2 catalyst (Figure 10c). On the other hand, under lean-burn conditions $(\lambda=1.03), 100 \%$ conversion of $\mathrm{CO}$ was occurred over the two commercial catalysts (OEM IV and OEM V/VI), while $\mathrm{CH}_{4}$ oxidation efficiency reached $93 \%$ and $99 \%$, respectively. PROMETHEUS full scale catalyst 15PROM2 presented full $\mathrm{CO}$ and $\mathrm{CH}_{4}$ conversion (Figure 10d,e). Finally, in all cases poor NO reduction reaction efficiency was observed (OEM IV: $15 \%$, OEM V/VI: 22\% and 15PROM2: 6\%, Figure 10f). It should be stressed out that PROMETHEUS full-scale catalyst (15PROM2) presents lower light-off temperatures comparative to the corresponding commercial catalysts, with high conversion (\%) values of the three toxic gases, $\mathrm{CO}, \mathrm{CH}_{4}, \mathrm{NO}$ even though it consists of lower concentration of PGMs (Pd and $\mathrm{Rh}$ ). This proves the successful replacement of PGMs (85.1\%) by $\mathrm{Cu}$. 


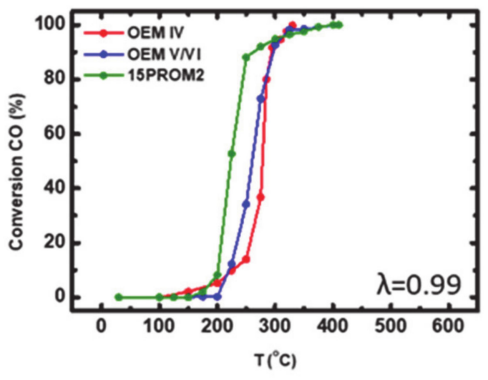

(a)

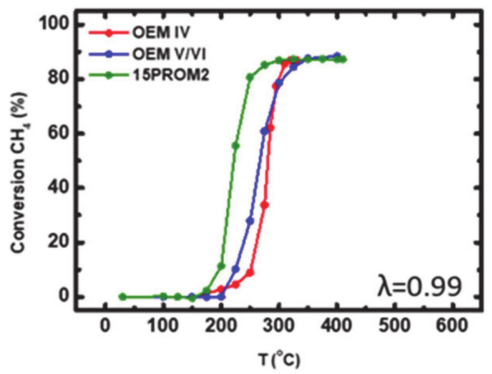

(b)

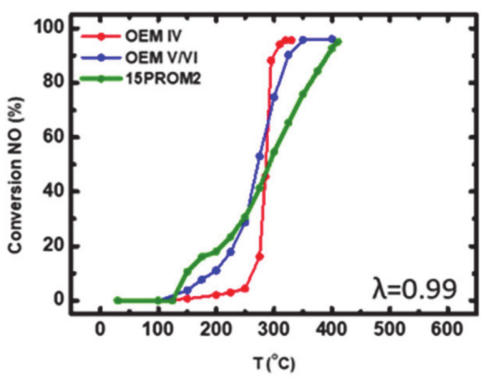

(c)

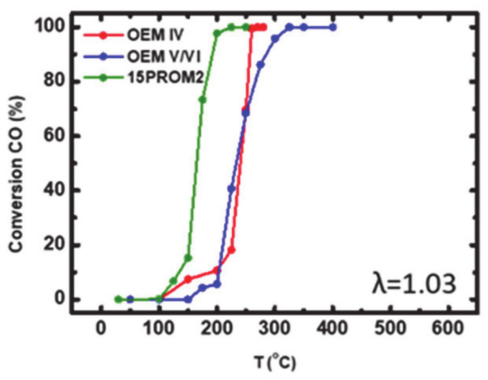

(d)

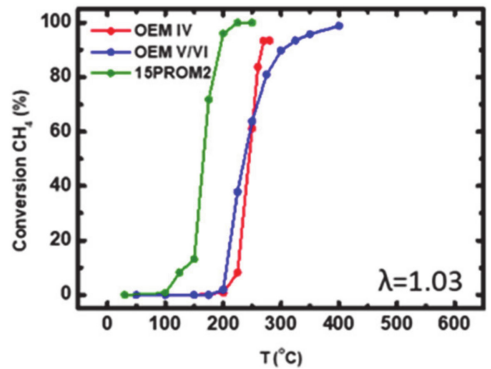

(e)

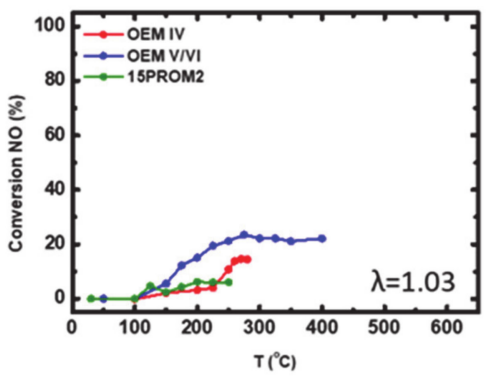

(f)

Figure 10. Light-off curves for the (\%) conversion of: (a) $\mathrm{CO}$; (b) $\mathrm{CH}_{4}$; (c) $\mathrm{NO}$ under rich-burn conditions $(\lambda=0.99) ;(\mathbf{d}) \mathrm{CO} ;(\mathbf{e}) \mathrm{CH}_{4} ;(\mathbf{f}) \mathrm{NO}$ under lean-burn conditions $(\lambda=1.03)$ over commercial catalysts OEM IV, OEM V/VI and PROMETHEUS Full-scale monolithic catalyst 15PROM2.

Table 5. Comparison of tested catalysts OEM IV, OEM V/VI and 15PROM2 under rich-burn conditions $(\lambda=0.99)$.

\begin{tabular}{|c|c|c|c|c|c|c|c|c|c|c|c|c|}
\hline \multirow[b]{2}{*}{ Catalyst } & \multicolumn{4}{|c|}{ CO Oxidation } & \multicolumn{4}{|c|}{$\mathrm{CH}_{4}$ Oxidation } & \multicolumn{4}{|c|}{ NO Reduction } \\
\hline & $\begin{array}{c}\mathrm{T}_{50} \\
\left({ }^{\circ} \mathrm{C}\right)\end{array}$ & $\begin{array}{c}\mathrm{T}_{90} \\
\left({ }^{\circ} \mathrm{C}\right)\end{array}$ & $\begin{array}{c}\mathrm{T}_{99} \\
\left({ }^{\circ} \mathrm{C}\right)\end{array}$ & $\begin{array}{c}\text { Max. } \\
\text { Efficiency } \\
(\%)\end{array}$ & $\begin{array}{c}\mathrm{T}_{50} \\
\left({ }^{\circ} \mathrm{C}\right)\end{array}$ & $\begin{array}{c}\mathrm{T}_{90} \\
\left({ }^{\circ} \mathrm{C}\right)\end{array}$ & $\begin{array}{c}\mathrm{T}_{99} \\
\left({ }^{\circ} \mathrm{C}\right)\end{array}$ & $\begin{array}{c}\text { Max. } \\
\text { Efficiency } \\
(\%)\end{array}$ & $\begin{array}{c}\mathrm{T}_{50} \\
\left({ }^{\circ} \mathrm{C}\right)\end{array}$ & $\begin{array}{c}\mathrm{T}_{90} \\
\left({ }^{\circ} \mathrm{C}\right)\end{array}$ & $\begin{array}{c}\mathrm{T}_{99} \\
\left({ }^{\circ} \mathrm{C}\right)\end{array}$ & $\begin{array}{c}\text { Max. } \\
\text { Efficiency } \\
(\%)\end{array}$ \\
\hline OEM IV & 280 & 293 & 330 & $100 \%$ & 280 & - & - & $87 \%$ & 286 & 300 & - & $96 \%$ \\
\hline OEM V/VI & 260 & 296 & 370 & $100 \%$ & 265 & - & - & $88 \%$ & 270 & 325 & - & $96 \%$ \\
\hline 15PROM2 & 220 & 260 & 370 & $100 \%$ & 220 & - & - & $87 \%$ & 290 & 390 & - & $96 \%$ \\
\hline
\end{tabular}

Table 6. Comparison of tested catalysts OEM IV, OEM V/VI and 15PROM2 under lean-burn conditions $(\lambda=1.03)$.

\begin{tabular}{|c|c|c|c|c|c|c|c|c|c|c|c|c|}
\hline \multirow[b]{2}{*}{ Catalyst } & \multicolumn{4}{|c|}{ CO Oxidation } & \multicolumn{4}{|c|}{$\mathrm{CH}_{4}$ Oxidation } & \multicolumn{4}{|c|}{ NO Reduction } \\
\hline & $\begin{array}{c}\mathrm{T}_{50} \\
\left({ }^{\circ} \mathrm{C}\right)\end{array}$ & $\begin{array}{c}\mathrm{T}_{90} \\
\left({ }^{\circ} \mathrm{C}\right)\end{array}$ & $\begin{array}{l}\mathrm{T}_{99} \\
\left({ }^{\circ} \mathrm{C}\right)\end{array}$ & $\begin{array}{c}\text { Max. } \\
\text { Efficiency } \\
(\%)\end{array}$ & $\begin{array}{c}\mathrm{T}_{50} \\
\left({ }^{\circ} \mathrm{C}\right)\end{array}$ & $\begin{array}{c}\mathrm{T}_{90} \\
\left({ }^{\circ} \mathrm{C}\right)\end{array}$ & $\begin{array}{c}\mathrm{T}_{99} \\
\left({ }^{\circ} \mathrm{C}\right)\end{array}$ & $\begin{array}{c}\text { Max. } \\
\text { Efficiency } \\
(\%)\end{array}$ & $\begin{array}{c}\mathrm{T}_{50} \\
\left({ }^{\circ} \mathrm{C}\right)\end{array}$ & $\begin{array}{c}\mathrm{T}_{90} \\
\left({ }^{\circ} \mathrm{C}\right)\end{array}$ & $\begin{array}{c}\mathrm{T}_{99} \\
\left({ }^{\circ} \mathrm{C}\right)\end{array}$ & $\begin{array}{c}\text { Max. } \\
\text { Efficiency } \\
(\%)\end{array}$ \\
\hline OEM IV & 240 & 258 & 260 & $100 \%$ & 244 & 268 & - & $93 \%$ & - & - & - & $15 \%$ \\
\hline OEM V/VI & 233 & 285 & 320 & $100 \%$ & 237 & 305 & 400 & $99 \%$ & - & - & - & $22 \%$ \\
\hline 15PROM2 & 160 & 190 & 210 & $100 \%$ & 160 & 190 & 215 & $100 \%$ & - & - & - & $6 \%$ \\
\hline
\end{tabular}




\subsubsection{Comparison of the Tested Fresh Catalysts}

The impact of the strictest emission limits on the emissions of vehicles tailpipe pollutants is reflected on the development of the catalytic converters, suitable for the corresponding Euro protocol. A higher PGM content is observed on catalysts of the latest Euro-IV $\left(108 \mathrm{~g} / \mathrm{ft}^{3}\right)$ and Euro-V/VI $\left(101 \mathrm{~g} / \mathrm{ft}^{3}\right)$ protocols (catalysts OEM-IV and OEM-V/VI) compared with catalysts of Euro-III protocol $\left(32 \mathrm{~g} / \mathrm{ft}^{3}\right.$, catalyst OEM-III). This increased PGM content has a significant impact on the catalytic activity and properties of the catalysts, as indicated by the experimental results (Tables 3-6). Catalysts that meet the requirements of strictest Euro protocols (Euro IV and Euro V/VI, catalysts OEM IV and OEM V/VI, respectively) with higher metal content are characterized by low light-off temperatures which are achieved for all oxidation and reduction reactions. This improved catalytic activity is observed for both rich-burn and lean-burn conditions.

PROMETHEUS catalysts exhibited high and comparable catalytic activity to the corresponding commercial TWC catalysts, proving that copper can successfully replace a part of PGMs. The most interesting results are observed for the oxidation of $\mathrm{CH}_{4}$ over 15 PROM2 catalyst, which is achieved at lower temperatures for both rich-burn $\left(\mathrm{T}_{50} \approx 220\right)$ and lean-burn $\left(\mathrm{T}_{50} \approx 160\right.$ and $\mathrm{T}_{90} \approx 190$ ) conditions. This performance is better even than a commercially available EURO-V/VI catalyst $\left(\mathrm{T}_{50} \approx 237\right.$ and $\mathrm{T}_{90} \approx 305$ for lean-burn conditions) and indicates the beneficial effect of the copper presence. Only on the reduction of NO the values of $\mathrm{T}_{50} \approx 290$ and $\mathrm{T}_{90} \approx 390$ are higher compared to the corresponding achieved values of EURO-IV $\left(\mathrm{T}_{50} \approx 286\right.$ and $\left.\mathrm{T}_{90} \approx 300\right)$ and EURO-V/VI $\left(\mathrm{T}_{50} \approx 270\right.$ and $\mathrm{T}_{90} \approx 325$ ) catalysts.

As $\mathrm{Rh}$ is the metal that catalyze the NO reduction, the higher temperature values of PROMETHEUS catalyst 15PROM2 are linked with the low Rh content. Further improvement to the NO reduction activity of PROMETHEUS, can take place with the change of the ratio of oxidizing/reduction metals of the catalyst. While for the commercial catalysts, the $\mathrm{Pd} / \mathrm{Rh}$ ratio varies from $82 / 18$ to $92 / 8$, for PROMETHEUS the specific ratio $(\mathrm{Cu}+\mathrm{Pd}$ over $\mathrm{Rh}$ is $96.5 / 3.5$ ). A change in the specific ratio (reducing $\mathrm{Pd}$ in favor of $\mathrm{Rh}$ ) keeping the same overall PGM concentration could enhance the already very good performance of PROMETHEUS catalyst over the commercial ones.

\subsection{The Effect of Ageing in Catalytic Activity}

Automotive three-Way Catalysts, the most widely employed gasoline exhaust after treatment devices, are able to perform a simultaneous reduction of more than $90 \%$ of the engine-out $\mathrm{CO}, \mathrm{HC}$ and $\mathrm{NO}_{\mathrm{x}}$ emissions and are usually operated in a wide temperature range from 150 to $1000{ }^{\circ} \mathrm{C}$ in oscillating conditions around stoichiometric air-to-fuel ratio, fluttering between oxidant and reducing environment and in presence of water vapor in a stream. Operation of TWC under extremely harsh conditions $\left(\mathrm{T}>850^{\circ} \mathrm{C}\right)$ can cause deactivation of the catalyst, a phenomenon called thermal ageing, presenting a decreased conversion efficiency and higher light-off temperatures. Thermal ageing is linked to the modification of the washcoat structure, called sintering, following by a loss of active surface area via structural modification of the porous support with a decrease of surface area of the carrier [31,32]. As a result, stringent emissions standards require high efficiency in emissions abatement and catalyst performance at high mileage [33].

Based on the above, OEMs and aftermarket TWC manufactures use different ageing methods such as, vehicle ageing, engine bench ageing or laboratory ageing process, with the latter to be the most widespread over the last years since it is proved to be a time-saving method by presenting high efficiency. Vehicle ageing method is actually close to real road driving condition but, on the other hand, it is time-consuming, it takes more manpower and the cost is high. Furthermore, according to recent publications of Centre Research Fiat and University of Torino, after applying comparative tests of laboratory ageing, real on vehicle aging and engine bench aging it was proved the similar results of gases conversion (\%) with no significant variations [34-36]. 
In this work a hydrothermal laboratory ageing protocol was used for the produced fullscale PROMETHEUS monolithic catalysts (5PROM2 and 15PROM2) and the commercial catalysts (OEM III, OEM IV, OEM V/VI) which is able to overcome the limitations of accelerated engine bench tests ensuring the simulation of a catalytic converter mileage under real life conditions. According to the protocol each catalyst was heated up to $1050{ }^{\circ} \mathrm{C}$ for $4 \mathrm{~h}$ under $10 \% \mathrm{H}_{2} \mathrm{O}$ in air flow and then their performance was evaluated under richburn $(\lambda=0.99)$ and lean-burn $(\lambda=1.03)$ conditions for the abatement of $\mathrm{CO}, \mathrm{CH}_{4}$ and NO. (Figure 11). Need to be mentioned that, the researchers of the Centre Research FIAT (CRF) and University of Torino concluded that hydrothermal ageing at $1100{ }^{\circ} \mathrm{C}$ for $7 \mathrm{~h}$ simulate Light Temperature for $\mathrm{CO}$ and $\mathrm{HC}$ of 80,000 real kilometers.

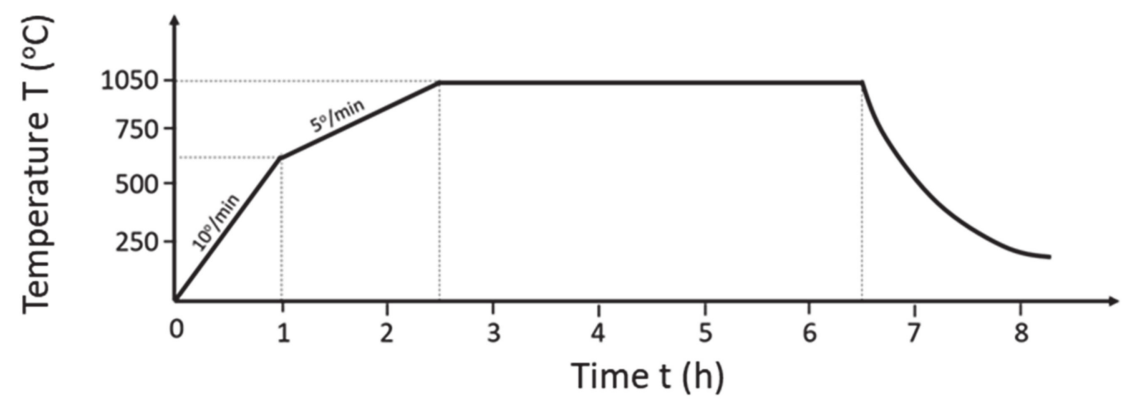

Figure 11. Ageing process heating protocol. Atmosphere: $10 \% \mathrm{H}_{2} \mathrm{O}$ in air.

The authors have, also, applied a catalyst hydrothermal ageing protocol according to international legislation standards (the legislation indicates ageing simulating 160,000 Km of real run) at $850{ }^{\circ} \mathrm{C}$ for $16 \mathrm{~h}$ to the catalysts of this study indicating mild deactivation (for this reason the results are not presented, since they do not offer further conclusions for the performance of the catalysts as compared with the fresh ones). Under these circumstances the ageing protocol near to melting point of copper $\left(1085^{\circ} \mathrm{C}\right)$ was used in order to have a more severe environment for the copper-based PROMETHEUS catalysts. A partial $\mathrm{Cu}$ leaching was observed during the ageing process without the catalytic efficiency of the catalysts being affected severely.

3.2.1. Catalytic Efficiency of AOEM III with A5PROM2 Full Scale Catalyst (84.4\% Substitution of PGMs with Copper NanoParticles)

The aged at $1050^{\circ} \mathrm{C}$ for $4 \mathrm{~h}$ (according to the above-mentioned protocol) commercial catalyst AOEM III and PROMETHEUS full scale monolithic catalyst 5PROM2, were tested under both rich-burn $(\lambda=0.99)$ and lean-burn $(\lambda=1.03)$ conditions, for the abatement of the three toxic gases $\mathrm{CO}, \mathrm{CH}_{4}$ and NO. Corresponding light-off curves are shown in Figure 12. Important activity indication values for catalysts characterization are summarized in Tables 7 and 8, respectively.

As shown in Tables 7 and 8, a significant degradation in catalytic activity was observed after catalyst ageing procedure. According to the results, in rich-burn conditions $(\lambda=0.99)$ the two catalysts were active at $\mathrm{T}>300{ }^{\circ} \mathrm{C}$ and $\mathrm{T}>370{ }^{\circ} \mathrm{C}$, respectively. It is proved that $\mathrm{CO}$ oxidation efficiency reached 94 and $65 \%$ in each case (Figure 12a), while $\mathrm{CH}_{4}$ oxidation efficiency was limited to 87 and $58 \%$, respectively (Figure 12b). Furthermore, $\mathrm{NO}$ reduction reached $50 \%$ at $550{ }^{\circ} \mathrm{C}$ for AOEM III catalyst and only $6 \%$ for A5PROM2 catalyst (Figure 12c). On the other hand, under lean-burn conditions $(\lambda=1.03)$ catalysts were active at $\mathrm{T}>300{ }^{\circ} \mathrm{C}$ and $\mathrm{T}>350{ }^{\circ} \mathrm{C}$, respectively. CO conversion reached $100 \%$ over AOEM III and $83 \%$ over A5PROM2 catalyst (Figure $12 \mathrm{~d}$ ), while $\mathrm{CH}_{4}$ oxidation reached $94 \%$ for AOEM III and $81 \%$ for A5PROM2 catalyst (Figure 12e). Finally, NO reduction was very low (AOEM III: 5\%, A5PROM2: 0), possibly due to surface oxidation of Rh nanoparticles of the catalysts (Figure 12f). 


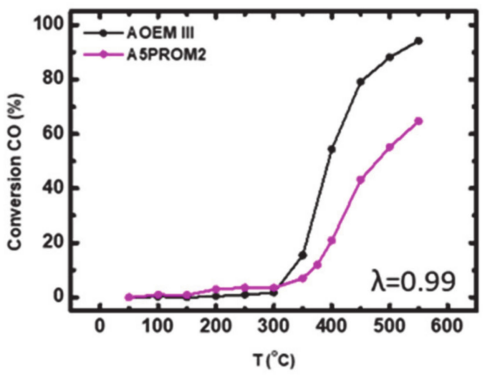

(a)

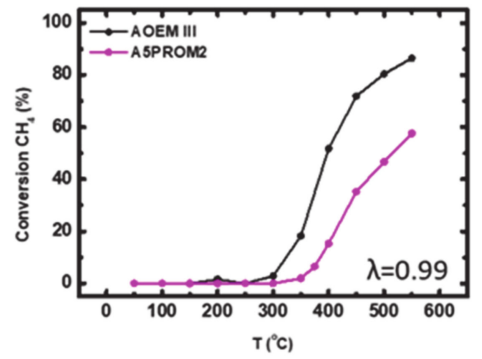

(b)

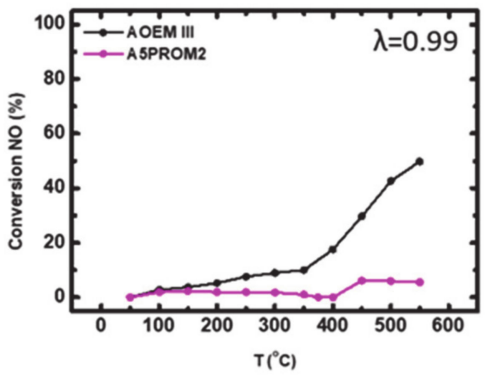

(c)

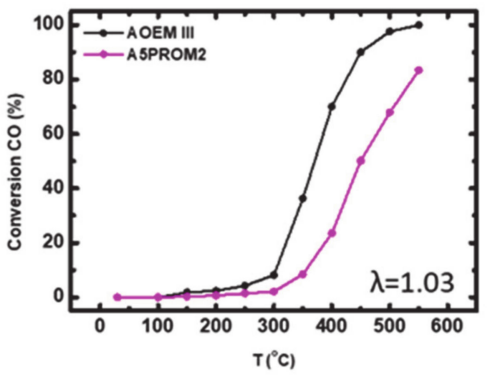

(d)

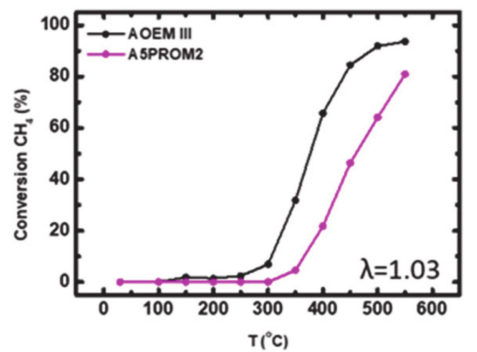

(e)

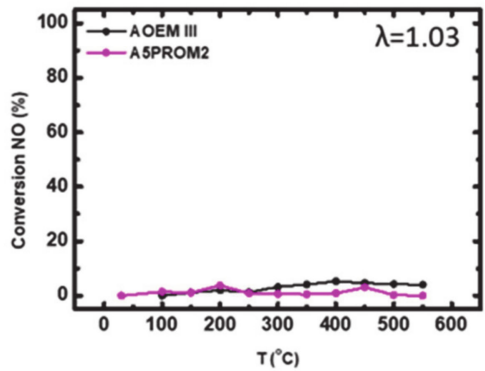

(f)

Figure 12. Light-off curves for the (\%) conversion of: (a) $\mathrm{CO} ;(\mathbf{b}) \mathrm{CH}_{4} ;$ (c) $\mathrm{NO}$ under rich-burn conditions $(\lambda=0.99)$; (d) $\mathrm{CO}$; (e) $\mathrm{CH}_{4}$; (f) $\mathrm{NO}$ under lean-burn-conditions $(\lambda=1.03)$ over aged commercial catalyst AOEM III and PROMETHEUS Full Scale monolithic catalyst 5PROM2.

Table 7. Comparison of aged tested catalysts OEM III and 5PROM2 under rich-burn conditions $(\lambda=0.99)$.

\begin{tabular}{|c|c|c|c|c|c|c|c|c|c|c|c|c|}
\hline \multirow[b]{2}{*}{ Catalyst } & \multicolumn{4}{|c|}{ CO Oxidation } & \multicolumn{4}{|c|}{$\mathrm{CH}_{4}$ Oxidation } & \multicolumn{4}{|c|}{ NO Reduction } \\
\hline & $\begin{array}{c}\mathrm{T}_{50} \\
\left({ }^{\circ} \mathrm{C}\right)\end{array}$ & $\begin{array}{c}\mathrm{T}_{90} \\
\left({ }^{\circ} \mathrm{C}\right)\end{array}$ & $\begin{array}{c}\mathrm{T}_{99} \\
\left({ }^{\circ} \mathrm{C}\right)\end{array}$ & $\begin{array}{c}\text { Max. } \\
\text { Efficiency } \\
(\%)\end{array}$ & $\begin{array}{c}\mathrm{T}_{50} \\
\left({ }^{\circ} \mathrm{C}\right)\end{array}$ & $\begin{array}{c}\mathrm{T}_{90} \\
\left({ }^{\circ} \mathrm{C}\right)\end{array}$ & $\begin{array}{c}\mathrm{T}_{99} \\
\left({ }^{\circ} \mathrm{C}\right)\end{array}$ & $\begin{array}{c}\text { Max. } \\
\text { Efficiency } \\
(\%)\end{array}$ & $\begin{array}{c}\mathrm{T}_{50} \\
\left({ }^{\circ} \mathrm{C}\right)\end{array}$ & $\begin{array}{c}\mathrm{T}_{90} \\
\left({ }^{\circ} \mathrm{C}\right)\end{array}$ & $\begin{array}{c}\mathrm{T}_{99} \\
\left({ }^{\circ} \mathrm{C}\right)\end{array}$ & $\begin{array}{c}\text { Max. } \\
\text { Efficiency } \\
(\%)\end{array}$ \\
\hline AOEM III & 400 & 515 & - & 94 & 400 & - & - & 87 & 550 & - & - & 50 \\
\hline A5PROM2 & 482 & - & - & 65 & 514 & - & - & 58 & - & - & - & 6 \\
\hline
\end{tabular}

Table 8. Comparison of aged tested catalysts OEM III and 5PROM2 for rich-burn conditions $(\lambda=1.03)$.

\begin{tabular}{|c|c|c|c|c|c|c|c|c|c|c|c|c|}
\hline \multirow[b]{2}{*}{ Catalyst } & \multicolumn{4}{|c|}{ CO Oxidation } & \multicolumn{4}{|c|}{$\mathrm{CH}_{4}$ Oxidation } & \multicolumn{4}{|c|}{ NO Reduction } \\
\hline & $\begin{array}{c}\mathrm{T}_{50} \\
\left({ }^{\circ} \mathrm{C}\right)\end{array}$ & $\begin{array}{c}\mathrm{T}_{90} \\
\left({ }^{\circ} \mathrm{C}\right)\end{array}$ & $\begin{array}{c}\mathrm{T}_{99} \\
\left({ }^{\circ} \mathrm{C}\right)\end{array}$ & $\begin{array}{c}\text { Max. } \\
\text { Efficiency } \\
(\%)\end{array}$ & $\begin{array}{c}\mathrm{T}_{50} \\
\left({ }^{\circ} \mathrm{C}\right)\end{array}$ & $\begin{array}{c}\mathrm{T}_{90} \\
\left({ }^{\circ} \mathrm{C}\right)\end{array}$ & $\begin{array}{c}\mathrm{T}_{99} \\
\left({ }^{\circ} \mathrm{C}\right)\end{array}$ & $\begin{array}{c}\text { Max. } \\
\text { Efficiency } \\
(\%)\end{array}$ & $\begin{array}{c}\mathrm{T}_{50} \\
\left({ }^{\circ} \mathrm{C}\right)\end{array}$ & $\begin{array}{c}\mathrm{T}_{90} \\
\left({ }^{\circ} \mathrm{C}\right)\end{array}$ & $\begin{array}{c}\mathrm{T}_{99} \\
\left({ }^{\circ} \mathrm{C}\right)\end{array}$ & $\begin{array}{c}\text { Max. } \\
\text { Efficiency } \\
(\%)\end{array}$ \\
\hline AOEM III & 370 & 450 & 525 & 100 & 370 & 490 & - & 94 & - & - & - & 5 \\
\hline A5PROM2 & 449 & - & - & 83 & 460 & - & - & 81 & - & - & - & 0 \\
\hline
\end{tabular}


3.2.2. Catalytic Efficiency of AOEM IV and AOEM V/VI with A15PROMW Full Scale Catalyst (85.1\% substitution of PGMs with Copper NanoParticles)

The aged commercial catalysts AOEM IV, AOEM V/VI and PROMETHEUS full-scale catalyst 15PROM2 were tested under both rich-burn $(\lambda=0.99)$ and lean-burn $(\lambda=1.03)$ conditions, for the abatement of $\mathrm{CO}, \mathrm{CH}_{4}$ and $\mathrm{NO}$. Corresponding light-off curves are shown in Figure 13. Important activity indication values for catalysts characterization are summarized in Tables 9 and 10, respectively.

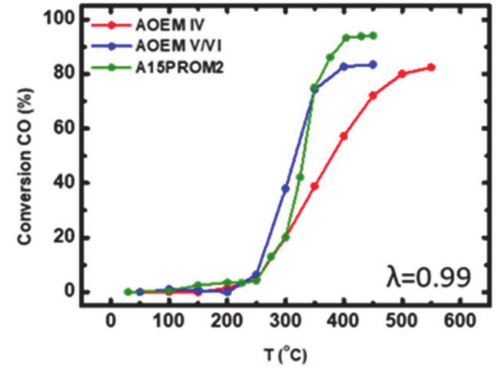

(a)

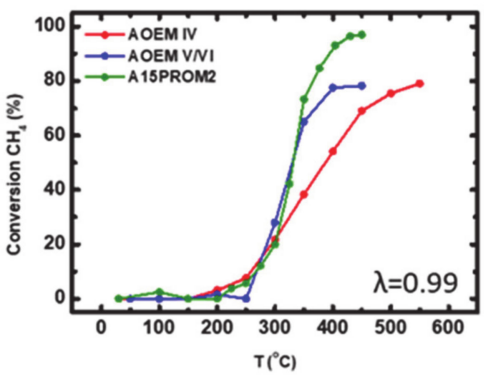

(b)

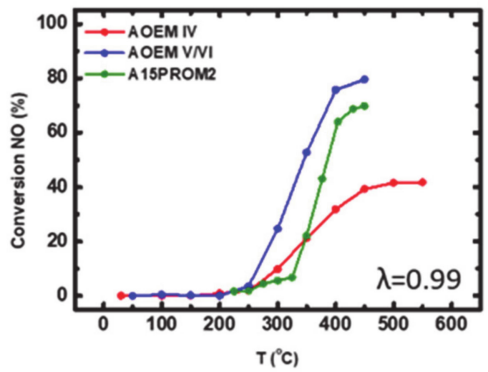

(c)

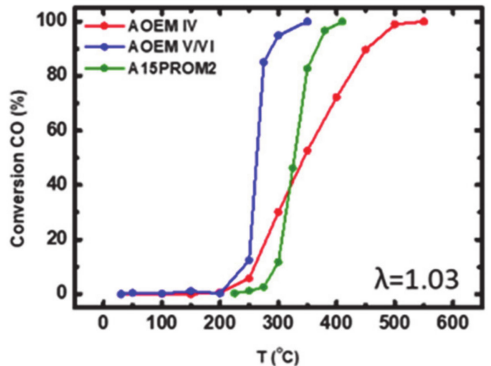

(d)

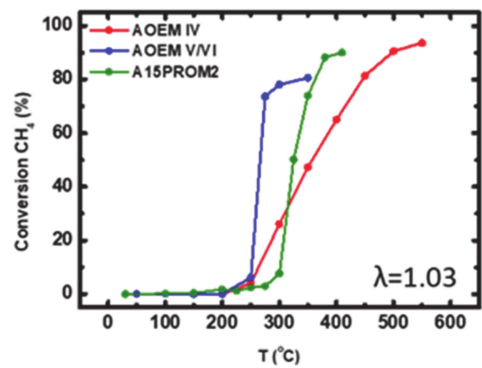

(e)

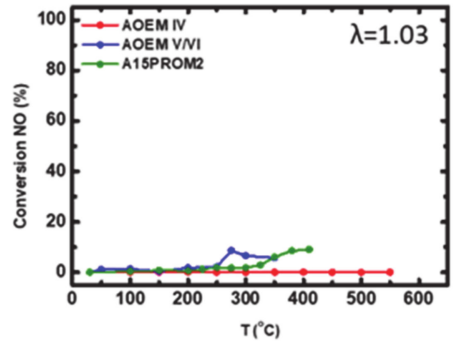

(f)

Figure 13. Light-off curves for the conversion (\%) of: (a) $\mathrm{CO}$; (b) $\mathrm{CH}_{4}$; (c) $\mathrm{NO}$ under rich-burn conditions $(\lambda=0.99)$; (d) $\mathrm{CO}$; (e) $\mathrm{CH}_{4}$; (f) $\mathrm{NO}$ under lean-burn-conditions $(\lambda=1.03)$ over aged commercial catalysts AOEM IV, OEM V/VI and PROMETHEUS Full Scale monolithic catalyst 15PROM2.

Table 9. Comparison of aged tested catalysts AOEM IV, AOEM V/VI and 15PROM2 under rich-burn conditions $(\lambda=0.99)$.

\begin{tabular}{|c|c|c|c|c|c|c|c|c|c|c|c|c|}
\hline \multirow[b]{2}{*}{ Catalyst } & \multicolumn{4}{|c|}{ CO Oxidation } & \multicolumn{4}{|c|}{$\mathrm{CH}_{4}$ Oxidation } & \multicolumn{4}{|c|}{ NO Reduction } \\
\hline & $\begin{array}{c}\mathrm{T}_{50} \\
\left({ }^{\circ} \mathrm{C}\right)\end{array}$ & $\begin{array}{c}\mathrm{T}_{90} \\
\left({ }^{\circ} \mathrm{C}\right)\end{array}$ & $\begin{array}{c}\mathrm{T}_{99} \\
\left({ }^{\circ} \mathrm{C}\right)\end{array}$ & $\begin{array}{c}\text { Max. } \\
\text { Efficiency } \\
(\%)\end{array}$ & $\begin{array}{c}\mathrm{T}_{50} \\
\left({ }^{\circ} \mathrm{C}\right)\end{array}$ & $\begin{array}{c}\mathrm{T}_{90} \\
\left({ }^{\circ} \mathrm{C}\right)\end{array}$ & $\begin{array}{c}\mathrm{T}_{99} \\
\left({ }^{\circ} \mathrm{C}\right)\end{array}$ & $\begin{array}{c}\text { Max. } \\
\text { Efficiency } \\
(\%)\end{array}$ & $\begin{array}{c}\mathrm{T}_{50} \\
\left({ }^{\circ} \mathrm{C}\right)\end{array}$ & $\begin{array}{c}\mathrm{T}_{90} \\
\left({ }^{\circ} \mathrm{C}\right)\end{array}$ & $\begin{array}{c}\mathrm{T}_{99} \\
\left({ }^{\circ} \mathrm{C}\right)\end{array}$ & $\begin{array}{c}\text { Max. } \\
\text { Efficiency } \\
(\%)\end{array}$ \\
\hline AOEM IV & 390 & - & - & 82 & 390 & - & - & 79 & - & - & - & 42 \\
\hline AOEM V/VI & 315 & - & - & 83 & 325 & - & - & 78 & 340 & - & - & 80 \\
\hline A15PROM2 & 330 & 390 & - & 94 & 330 & 395 & - & 97 & 390 & - & - & 70 \\
\hline
\end{tabular}


Table 10. Comparison of aged tested catalysts AOEM IV, AOEM V/VI and 15PROM2 under lean-burn conditions $(\lambda=1.03)$.

\begin{tabular}{|c|c|c|c|c|c|c|c|c|c|c|c|c|}
\hline \multirow[b]{2}{*}{ Catalyst } & \multicolumn{4}{|c|}{ CO Oxidation } & \multicolumn{4}{|c|}{$\mathrm{CH}_{4}$ Oxidation } & \multicolumn{4}{|c|}{ NO Reduction } \\
\hline & $\begin{array}{c}\mathrm{T}_{50} \\
\left({ }^{\circ} \mathrm{C}\right)\end{array}$ & $\begin{array}{c}\mathrm{T}_{90} \\
\left({ }^{\circ} \mathrm{C}\right)\end{array}$ & $\begin{array}{c}\mathrm{T}_{99} \\
\left({ }^{\circ} \mathrm{C}\right)\end{array}$ & $\begin{array}{c}\text { Max. } \\
\text { Efficiency } \\
(\%)\end{array}$ & $\begin{array}{c}\mathrm{T}_{50} \\
\left({ }^{\circ} \mathrm{C}\right)\end{array}$ & $\begin{array}{c}\mathrm{T}_{90} \\
\left({ }^{\circ} \mathrm{C}\right)\end{array}$ & $\begin{array}{c}\mathrm{T}_{99} \\
\left({ }^{\circ} \mathrm{C}\right)\end{array}$ & $\begin{array}{c}\text { Max. } \\
\text { Efficiency } \\
(\%)\end{array}$ & $\begin{array}{c}\mathrm{T}_{50} \\
\left({ }^{\circ} \mathrm{C}\right)\end{array}$ & $\begin{array}{c}\mathrm{T}_{90} \\
\left({ }^{\circ} \mathrm{C}\right)\end{array}$ & $\begin{array}{c}\mathrm{T}_{99} \\
\left({ }^{\circ} \mathrm{C}\right)\end{array}$ & $\begin{array}{c}\text { Max. } \\
\text { Efficiency } \\
(\%)\end{array}$ \\
\hline AOEM IV & 345 & 450 & 500 & 100 & 358 & 495 & - & 94 & - & - & - & 0 \\
\hline AOEM V/VI & 260 & 289 & 345 & 100 & 260 & - & - & 81 & - & - & - & 9 \\
\hline A15PROM2 & 330 & 366 & 404 & 100 & 325 & 410 & - & 90 & - & - & - & 9 \\
\hline
\end{tabular}

After ageing at $1050{ }^{\circ} \mathrm{C}$, catalytic activity was detected only above 250, 250 and $270{ }^{\circ} \mathrm{C}$ under rich-burn conditions over AOEM IV, AOEM V/VI and A15PROM2 catalysts, respectively. CO oxidation efficiency reached 82,83 and $94 \%$ (Figure 13a), while $\mathrm{CH}_{4}$ oxidation efficiency limited to 79,78 and $97 \%$, respectively (Figure 13b). NO reduction reached $42 \%$ at $550{ }^{\circ} \mathrm{C}$ for AOEM IV, $80 \%$ at $450{ }^{\circ} \mathrm{C}$ for AOEM V/VI and $70 \%$ at $\sim 400{ }^{\circ} \mathrm{C}$ for A15PROM2 catalyst (Figure 13c). It can be noticed that A15PROM2 catalyst presents similar light-off temperature and maximum efficiency behavior compared with the original EURO V/VI benchmark. Furthermore, under lean-burn conditions $(\lambda=1.03)$ the catalysts were active above 250,230 and $300{ }^{\circ} \mathrm{C}$, respectively. CO conversion (\%) reached to $100 \%$ in each case (Figure 13d), while $\mathrm{CH}_{4}$ conversion (\%) was found equal to 94,81 and $90 \%$, respectively (Figure 13e). A15PROM2 presented similar maximum efficiency behavior with Original EURO V/VI benchmark, while a higher by $70^{\circ} \mathrm{C}$ light-off temperature was observed for the former, probably due to the severe ageing protocol that was implemented. The melting point of copper is $1085^{\circ} \mathrm{C}$ (very near to the ageing temperature of $1050{ }^{\circ} \mathrm{C}$ ) implying that part of the metal could be passing in liquid form, lowering the copper content of the catalyst and thus, the synergistic effect between copper and PGMs is decreased.

\section{Discussion}

The progress of the catalytic converters technology resulted in new type of catalysts, able to meet the requirements of the strictest Euro protocols for automotive emissions. These strictest emission limits are related with the protection of the environment, the prevention of climate change and the improvement of air quality, especially in the large urban centers, through the decrease of emission of the transport sector. Apart from the environmental point, the economic point of view is also important. The last generation catalytic converters require increased content of Platinum Group Metals (PGMs) in order to meet strict emission criteria and directions. This fact subsequently leads to elevated cost of the final product and dependence on the countries that produced the raw material. The research presented herein suggests an alternative approach that combines an effective catalytic system and lower cost. This performance is achieved by the use of copper, which according to the presented technology can successfully replace a significant amount of PGMs in the catalytic converters. According to the experimental results, the presented PROMETHEUS catalysts can successfully meet the Euro III and Euro V/VI emission protocols. More specific, catalyst 5PROM2 containing $5 \mathrm{gr} / \mathrm{ft}^{3}$ of PGMs presents similar or better catalytic activity when it is compared with OEM III containing $32 \mathrm{gr} / \mathrm{ft}^{3}$ PGMs. Furthermore, catalyst 15PROM2 containing $15 \mathrm{gr} / \mathrm{ft}^{3}$ of PGMs presents similar or better catalytic activity when it is compared with OEM IV and OEM V/VI containing more than $100 \mathrm{gr} / \mathrm{ft}^{3}$ PGMs. Overall, $85 \%$ reduction of PGM loading has been achieved by incorporating PROMETHEUS Substitution Technology with similar or better catalytic efficiency results. The reduction of NO under lean-burn conditions is the only exception, which can be attributed to the lower ratio of oxidation metals ( $\mathrm{Cu}$ and $\mathrm{Pd}$ ) and reduction metal (Rh) $28 / 1$ as compared to the original catalysts ( $\mathrm{Pd} / \mathrm{Rh}$ ratio between $10.5 / 1$ to $4.5 / 1$ ).

The pronounced higher activity of PROMETHEUS catalyst that contains $\sim 85 \%$ less PGM (or $\sim 7$ times less PGM), can be possibly attributed to synergistic phenomena between $\mathrm{Cu}$ and PGM metal nanoparticles and to high oxygen storage capacity of the selected 
Ceria-Zirconia ceramic support at low temperatures. The latter results in decoration of the metal particles surface with back spillover oxygen ionic species acting as in-situ activity promoters. According to the above and, based on the literature, we may propose the following mechanism. The high activity and stability of the catalyst is mainly attributed to the existence of $\mathrm{Cu}$ (I) species in the system and the destabilization of $\mathrm{Cu}$ (II) species, both due to e- transfer effects from the Rh, Pd metals to $\mathrm{Cu}$ and strong metal-support in ter-action phenomena. Oxygen ion species vacancies on the wash-coat support are favored, which results in weakening of the interaction between the adsorbed electronegative species from the gas phase to the surface metal oxide species. In addition, the ability of Ce (III) to get oxidized by steam in the temperature range $300-500{ }^{\circ} \mathrm{C}$ and produce $\mathrm{H}_{2}(\mathrm{~g})$ which can then cause the reduction of $\mathrm{Cu}(\mathrm{I})$ to $\mathrm{Cu}$, plays an important role. The latter step is of particular importance since the metal $\mathrm{Cu}$ formed therein serves the reduction of Ce (IV) thus completing the Ce (III)/Ce (IV) oxidation cycle. In the above-described synergy, it is also worth mentioning the recorded steam chemi-sorption on the surface of CuPt bimetallic catalysts, thus contributing to the critical step of Ce (III) oxidation and the formation of $\mathrm{H}_{2}$ [37-39]. In our future work, extensive mechanistic study will be take place in order to ensure the above mentioned and proposed mechanism and to fully explain the high catalytic efficiency of PROMETHEUS catalyst.

\section{Conclusions}

The two full-scale PROMETHEUS catalysts with loading $5 \mathrm{~g}$ PGMs $/ \mathrm{ft}^{3}$ and $15 \mathrm{~g}$ $\mathrm{PGMs} / \mathrm{ft}^{3}$ corresponding to EURO III catalyst and EURO IV /V/VI were tested for the abatement of toxic gases $\mathrm{CO}, \mathrm{CH}_{4}$ and NO. Furthermore, three commercial catalysts suitable for Euro III (catalyst OEM III), Euro IV (catalyst OEM IV) and Euro V/VI (catalyst OEM V/VI) protocol, have been used as benchmark and their catalytic efficiency has been tested for comparison reasons under the same catalytic conditions. The produced PROMETHEUS catalysts and the commercial catalysts were then aged at $1050{ }^{\circ} \mathrm{C}$ for $4 \mathrm{~h}$ and were evaluated as catalysts for the oxidation of $\mathrm{CO}$ and $\mathrm{CH}_{4}$ and the reduction of NO.

According to the results, 15PROM2 and A15PROM2 catalysts present in most cases better results compared to 5PROM2 and A5PROM2 catalysts due to higher PGMs loading, $15 \mathrm{~g}$ PGMs $/ \mathrm{ft}^{3}$. On the other hand, both fresh and aged PROMETHEUS catalysts present similar and, in some cases, better catalytic activity compared to corresponding commercial catalysts although they consist of $85 \%$ less PGMs, thus opening a new path for the production of catalytic converters.

\section{Patents}

European Patent of Prometheus: copper and noble metal polymetallic catalysts for engine flue gas treatment. EP3569309. Applicant Monolithos Catalysts and Recycling Ltd., Inventor: Iakovos Yakoumis.

Author Contributions: Conceptualization, I.Y.; materials preparation, A.M.M. and E.P.; materials characterization, A.M.M. and E.P.; catalytic test, A.M.M. and E.P.; writing—original draft preparation, I.Y., E.P. and A.M.M.; writing—-review and editing, all authors; supervision, I.Y.; project administration, E.P.; funding acquisition, I.Y. and E.P. All authors have read and agreed to the published version of the manuscript.

Funding: H2020-EU.2.3.1.-Mainstreaming SME support, especially through a dedicated instrument. H2020-EU.3.5.-SOCIETAL CHALLENGES-Climate action, Environment, Resource Efficiency and Raw Materials. Topic(s): SMEInst-11-2016-2017 Boosting the potential of small businesses in the areas of climate action, environment, resource efficiency and raw materials. No. 778893.

Institutional Review Board Statement: Not applicable.

Informed Consent Statement: Not applicable. 
Data Availability Statement: The data presented in this study are available on request from the corresponding author after obtaining permission of authorized person. The data are not publicly available due to data confidentiality resulting from the requirements of the accreditation.

Acknowledgments: The authors wish to acknowledge the help and support of Maria Papastergiou in the editing of the specific manuscript.

Conflicts of Interest: The authors declare no conflict of interest.

\section{References}

1. Kitco.com. Available online: https://www.kitco.com/ (accessed on 12 April 2021).

2. Taylor, K.C. Automobile Catalytic Converters. In Catalysis and Automotive Pollution Control, 1st ed.; Crucq, A., Frennet, A., Eds.; Elsevier: Amsterdam, The Netherlands, 1987; Volume 30, p. 97.

3. Lipshutz, B.H.; Pfeiffer, S.S. Copper: Organometallic Chemistry. In Encyclopedia of Inorganic and Bioinorganic Chemistry, 1st ed.; John Wiley \& Sons, Ltd.: Hoboken, NJ, USA, 2011. [CrossRef]

4. Kanwal, I.; Mujahid, A.; Rasool, N.; Rizwan, K.; Malik, A.; Ahmad, G.; Ali Shah, S.A.; Rashid, U.; Nasir, N.M. Palladium and Copper Catalyzed Sonogashira cross Coupling an Excellent Methodology for C-C Bond Formation over 17 Years: A Review. Catalysts 2010, 10, 443. [CrossRef]

5. Cao, Y.-X.; Dong, X.-Y.; Yang, J.; Jiang, S.-P.; Zhou, S.; Li, Z.-L.; Chen, G.-C.; Liu, X.-Y. A Copper-Catalyzed Sonogashira Coupling Reaction of Diverse Activated Alkyl Halides with Terminal Alkynes Under Ambient Conditions. Adv. Synth. Catal. 2020, 362, 2280-2284. [CrossRef]

6. Lakshmi Kantam, M.; Gadipelly, C.; Deshmukh, G.; Rajender Reddy, K.; Bhargava, S. Copper Catalyzed C-H Activation. Chem. Rec. 2019, 19, 1302-1318. [CrossRef] [PubMed]

7. Kirillova, M.V.; Fernandes, T.A.; André, V.; Kirillov, A.M. Mild C-H Functionalization of Alkanes Catalyzed by Bioinspired Copper (II) Cores. Org. Biomol. Chem. 2019, 17, 7706-7771. [CrossRef]

8. Lu, C.-Y.; Chang, W.-C.; Wey, M.-Y. $\mathrm{CuO} / \mathrm{CeO}_{2}$ catalysts prepared with different cerium supports for $\mathrm{CO}$ oxidation at low temperature. Mater. Chem. Phys. 2013, 141, 512-518. [CrossRef]

9. Zeng, S.; Wang, Y.; Ding, S.; Sattler, J.J.H.B.; Borodina, E.; Zhang, L.; Weckhuysen, B.M.; Su, H. Active sites over CuO/CeO 2 and inverse $\mathrm{CeO}_{2} / \mathrm{CuO}$ catalysts for preferential $\mathrm{CO}$ oxidation. J. Power Sources 2014, 256, 301-311. [CrossRef]

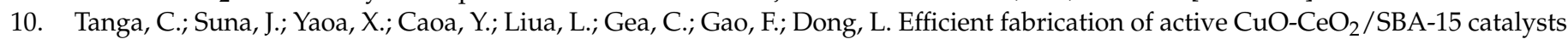
for preferential oxidation of $\mathrm{CO}$ by solid state impregnation. Appl. Catal. B 2014, 256, 301-311. [CrossRef]

11. Yu-Yao, Y.-F. The Oxidation of $\mathrm{CO}$ and $\mathrm{C}_{2} \mathrm{H}_{4}$ over Metal Oxides. J. Catal. 1975, 39, 104-114. [CrossRef]

12. Farrauto, R.J.; Wedding, B. Poisoning by $\mathrm{SO}_{x}$ of some base metal oxide auto exhaust catalysts. J. Catal. 1974, 33, 249-255. [CrossRef]

13. Fishel, N.A.; Lee, R.K.; Wilhelm, F.C. Poisoning of Vehicle Emission Control Catalysts by Sulfur Compounds. Environ. Sci. Technol. 1974, 8, 260-267. [CrossRef]

14. Luo, M.-F.; Fang, P.; He, M.; Xie, Y.-L. In situ XRD, Raman, and TPR studies of $\mathrm{CuO} / \mathrm{Al}_{2} \mathrm{O}_{3}$ catalysts for CO oxidation. J. Mol. Catal. A Chem. 2005, 239, 243-248. [CrossRef]

15. Martinez-Arias, A.; Fernadez-Garcia, M.; Galvez, O.; Coronado, J.M.; Anderson, J.A.; Conesa, J.C.; Soria, J.; Munuera, G. Comparative Study on Redox Properties and Catalytic Behavior for $\mathrm{CO}$ Oxidation of $\mathrm{CuO} / \mathrm{CeO}_{2}$ and $\mathrm{CuO} / \mathrm{ZrCeO} 4 \mathrm{Catalysts}$. J. Catal. 2000, 195, 207-216. [CrossRef]

16. Yang, Z.; He, B.; Lu, Z.; Hermansson, K. Physisorbed, Chemisorbed, and Oxidized CO on Highly Active Cu-CeO 2 (111). J. Phys. Chem. C 2010, 114, 4486-4494. [CrossRef]

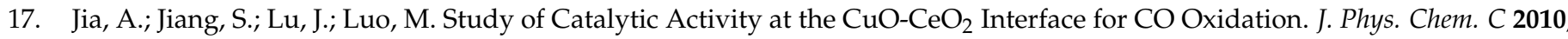
114, 21605-21610. [CrossRef]

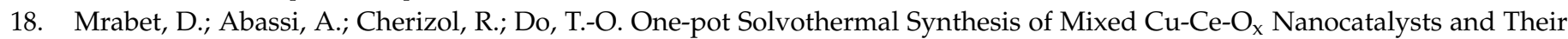
Catalytic Activity for Low Temperature CO Oxidation. Appl. Catal. A 2012, 447-448, 60-66. [CrossRef]

19. Aneggi, E.; Llorca, J.; Boaro, M.; Trovarelli, A. Surface-structure Sensitivity of CO Oxidation over Polycrystalline Ceria Powders. J. Catal. 2005, 234, 88-95. [CrossRef]

20. Pacella, M.; Carbujo, A.; Fabro, J.; Gulotto, M.; Xin, Q.; Natile, M.M.; Canu, P.; Cool, P.; Glisenti, A. PGM-free CuO/LaCoO 3 nanocomposites: New opportunities for TWC application. Appl. Catal. B 2018, 227, 446-458. [CrossRef]

21. Moretti, E.; Lenardaa, M.; Rielloa, P.; Storaro, L.; Talona, A.; Frattini, R.; Reyes-Carmona, A.; Jiménez-López, A.; RodríguezCastelló, E. Influence of synthesis parameters on the performance of $\mathrm{CeO}_{2}-\mathrm{CuO}$ and $\mathrm{CeO}_{2}-\mathrm{ZrO}_{2}-\mathrm{CuO}$ systems in the catalytic oxidation of CO in excess of hydrogen. Appl. Catal. B 2013, 129, 556-565. [CrossRef]

22. Sun, S.; Mao, D.; Yu, J.; Yang, Z.; Lua, G.; Mab, Z. Low-temperature CO oxidation on $\mathrm{CuO} / \mathrm{CeO}_{2}$ catalysts: The significant effect of copper precursor and calcination temperature. Catal. Sci. Technol. 2015, 5, 3166-3181. [CrossRef]

23. Papadopoulos, C.; Kappisa, K.; Papavasiliou, J.; Vakros, J.; Kuśmierz, M.; Gac, W.; Georgiou, Y.; Deligiannakis, Y.; Avgouropoulos, G. Copper-promoted ceria catalysts for CO oxidation reaction. Catal. Today 2020, 355, 647-653. [CrossRef]

24. Yakoumis, I. PROMETHEUS: A Copper Based Polymetallic Catalyst for Automotive Applications. Part I: Synthesis and Characterization. Materials 2021, 14, 622. [CrossRef] 
25. Bedford, R.E.; LaBarge, W.J. Base Metal Automotive Exhaust Catalyst with Improved Activity and Stability and Method of Making the Catalysts. U.S. Patent 5,063,193, 5 November 1991.

26. Shore, L.; Ruettinger, W.F.; Farrauto, R.J. Platinum Group Metal Promoted Copper Oxidation Catalysts and Methods for Carbon Monoxide Remediation. U.S. Patent 2002/0131915 A1, 19 September 2002.

27. Park, S.E.; Kim, G.-M.; Lee, Y.-J.; Chang, J.-S.; Han, S.-H. Method for Removing Nitrogen Oxides in Exhaust Gas by Selective Catalytic Reduction and Catalyst for Reduction of Nitrogen Oxides. U.S. Patent 5,879,645, 9 March 1999.

28. Hu, Y.; Dong, L.; Shen, M.; Liu, D.; Wang, J.; Ding, W.; Chen, Y. Influence of supports on the activities of copper oxide species in the low-temperature NO + CO reaction. Appl. Catal. B 2001, 31, 61-69. [CrossRef]

29. Yakoumis, I.; Moschovi, A.; Panou, M.; Panias, D. Single-Step Hydrometallurgical Method for the Platinum Group Metals Leaching from Commercial Spent Automotive Catalysts. J. Sustain. Metall. 2020, 6, 259-268. [CrossRef]

30. Dalianis, G.; Nanaki, E.; Xydis, G.; Zervas, E. Aspects to Greenhouse New Gas Mitigation Policies for Low Carbon Cities. Energies 2016, 9, 128. [CrossRef]

31. Neyestanaki, A.K.; Klingstedt, F.; Salmi, T.; Murzin, D.Y. Deactivation of Postcombustion Catalysts, a Review. Fuel 2014 83, 395-408. [CrossRef]

32. More, K.L.; Kenik, E.A.; Coffey, D.W.; Geer, T.S.; LaBarge, W.J.; Beckmeyer, R.F.; Theis, J. Thermally-Induced Microstructural Changes in a Three-Way Automotive Catalyst. SAE Tech. Paper Ser. 1997, 1255-1263. [CrossRef]

33. Winkler, A.; Ferri, D.; Hauert, R. Influence of Aging Effects on the Conversion Efficiency of Automotive Exhaust Gas Catalysts. Catal. Today 2010, 155, 140-146. [CrossRef]

34. Sheng, S.; Lai, Y.; Hao, C.; Hou, P.; Lv, T.; Ge, Y. Review of Rapid Ageing Testing Methods of Three-Way Catalyst for Gasoline Engine. Int. J. Veh. Perform. 2020, 6, 277-293. [CrossRef]

35. Kang, S.B.; Kwon, H.J.; Nam, I.-S.; Song, Y.I.; Oh, S.H. Activity Function for Describing Alteration of Three-Way Catalyst Performance over Palladium-Only Three-Way Catalysts by Catalyst Mileage. Int. Eng. Chem. Res. 2011, 50, 5499-5509. [CrossRef]

36. Giuliano, M.; Valsania, M.C.; Ticali, P.; Sartoretti, E.; Morandi, S.; Bensaid, S.; Ricchiardi, G.; Sgoi, M. Characterization of the Evolution of Noble Metal Particles in a Commercial Three-Way Catalyst: Correlation Between Real and Simulated Ageing. Catalysts 2021, 11, 247. [CrossRef]

37. Nicole, J.; Tsiplakides, D.; Pliangos, C.; Verykios, X.E.; Comninellis, C.; Vayenas, C.G. Electrochemical Promotion and MetalSupport Interactions. J. Catal. 2001, 204, 23-34. [CrossRef]

38. Vernoux, P.; Lizarraga, L.; Tsampas, M.N.; Sapountzi, F.M.; De Lucas-Consuegra, A.; Valverde, J.-L.; Souentie, S.; Vayenas, C.G.; Tsiplakides, D.; Balomenou, S.; et al. Ionically Conducting Ceramics as Active Catalyst Supports. Chem. Rev. 2013, 113, 8192-8260. [CrossRef]

39. Zafiris, G.S.; Gorte, R.J. Evidence for Low-Temperature Oxygen Migration from Ceria to Rh. J. Catal. 1993, 139, 561-567. [CrossRef] 